\title{
Medical Cannabis in Palliative Psychiatry: Clinical Aspects of Affective Regulation and Legal
}

\section{Challenges}

\author{
Bellman, Val ${ }^{* 1}$, Kiolbasa, Megan ${ }^{2}$, Vasquez Franjul, Manuel ${ }^{3}$, Namdev, Vaishalee ${ }^{4}$, Choi, Sarang ${ }^{5}$, \\ Isola, Sasank ${ }^{6}$
}

${ }^{1}$ Department of Psychiatry, UMKC School of Medicine, Kansas City, MO, 64108, USA

${ }^{2}$ Kansas City University, Kansas City, MO, 64106, USA

${ }^{3}$ Department of Psychiatry, Neurociencias HGH/ Universidad Iberoamericana, Santo Domingo, Dominican Republic

${ }^{4}$ Department of Psychiatry, Mahatma Gandhi Memorial Medical College, Indore, 452001 India

${ }^{5}$ Ateneo School of Medicine and Public Health, Don Eugenio Lopez Sr. Medical Complex, Ortigas Ave, Pasig, 1604

Metro Manila, Philippines

${ }^{6}$ American University of the Caribbean School of Medicine, Cupecoy, St. Maarten

*Corresponding author: Val Bellman; vvzzw8@umkc.edu

Received: 22 August 2021;

Accepted: 12 September 2021;

Published: 16 September 2021

\begin{abstract}
Millions of Americans use cannabis for medical purposes including but not limited to pain, nausea, mood changes and appetite stimulation. The use of cannabinoid in the palliative care setting is a relatively new trend. Given the fact that a patient receiving palliative care is not necessarily approaching death, the increasing need for palliative care as the American population ages, this literature review was compiled in order to examine the potential efficacy of cannabis in treating the mental health comorbidities of palliative care patients. We attempted to create the most comprehensive report on cannabinoid use in palliative psychiatry. It summarizes the most recently published science on cannabinoid use in palliative care patients and its impact on mood and anxiety symptoms. The mechanism of action of cannabinoids on their associated receptors was elucidated, as were the pharmacological roles that specific molecules in cannabinoids, like cannabidiolic acid and terpenes, play in cannabinoids' overall efficacy. The legal impediments to widespread cannabis use were also explored. While the potential efficacy of cannabinoids has proven to be mixed, more research is necessary to ensure that a potentially vital resource in treating palliative care patients does not go underutilized.
\end{abstract}

Keywords: cannabis, palliative care, depression, anxiety, legalization

\section{Introduction}

As physicians face an aging patient population and as cancer and other degenerative diseases common among the elderly become more prevalent, the need for effective palliative care will become more crucial. Cancer and degenerative diseases are often associated with significant comorbidities such as pain, anxiety, anorexia, and depression, among others ${ }^{[1]}$. In light of this, physicians must be willing to consider a wide variety of therapeutic options in order to make patients with chronic illness feel more comfortable, particularly if they are terminally ill. One therapeutic option in palliative care that has received increased attention in recent years is cannabis. While cannabis was initially used in pain control, its potential utility in ameliorating other chronic comorbidities warrants further investigation. One study suggests that it can be used to ameliorate depression, anxiety, and insomnia ${ }^{[2]}$. The goal of this literature review is to explore existing literature pertaining to the mechanism of action of medical cannabis, its use in emotional regulation, the potential risks and side effects associated with cannabis treatment, and the hurdles associated with its evolving legal status, concluding with speculation about its future as a mainstream therapy in palliative care. Particular emphasis will be placed on the role of cannabis in reducing depression, anxiety; the risk of cannabis abuse, dependence, and withdrawal; and side effects such as cannabis-induced euphoria and dysphoria. 


\section{Materials and Methods}

Narrative review of the literature synthesizing the findings of literature retrieved from searches of computerized databases e.g., PubMed, MEDLINE, Embase, PsycINFO, CENTRAL (Cochrane Controlled Register of Trials), state web resources, hand searches, and authoritative texts. We also adopted several figures in accordance with the iStock Standard License.

\section{Results and Discussion}

\section{Biochemical Basics of Medical Cannabis}

The common species of cannabis plants are C. sativa, C. indica and C. ruderalis. Cannabis has a complex chemical makeup, with more than 500 active components discovered so far ${ }^{[3]}$. In addition to having a wide variety of chemical structures representing almost all the chemical classes (e.g., sugars, hydrocarbons, steroids, mono and sesquiterpenes), it also demonstrates an equally complex biochemical profile, with evidence of these compounds interacting with one another. Of these components, the best-known and most studied are C21 terpenophenolic cannabinoids, especially (-)-D9trans-(6aR,10aR)-tetrahydrocannabinol (D9-THC). THC is also the most psychologically active component of the plant ${ }^{[4]}$. With the discovery of biochemically-analogous endogenous cannabinoid ligands and the discovery of synthetic cannabinoids, the term 'phytocannabinoids' is now used for psychoactive components isolated from the plant ${ }^{[5]}$. So far, more than 90 of these phytocannabinoids have been identified and are composed of C21 or C22 terpenophenolic compounds (including their breakdown products) produced by the cannabis plant ${ }^{[3,6,7]}$. These are further divided into 10 subclasses; namely, (-)-D9-transtetrahydrocannabinol (D9-THC), (-)-D8-transtetrahydrocannabinol (D8-THC), cannabinol (CBN), cannabidiol (CBD), cannabinodiol (CBND), cannabigerol (CBGs), cannabichromene (CBC), cannabicyclol (CBL), cannabielsoin (CBE), and cannabitriol (CBT) ${ }^{[3]}$. Figure 1 provides further information regarding the chemical structure of cannabinoids.

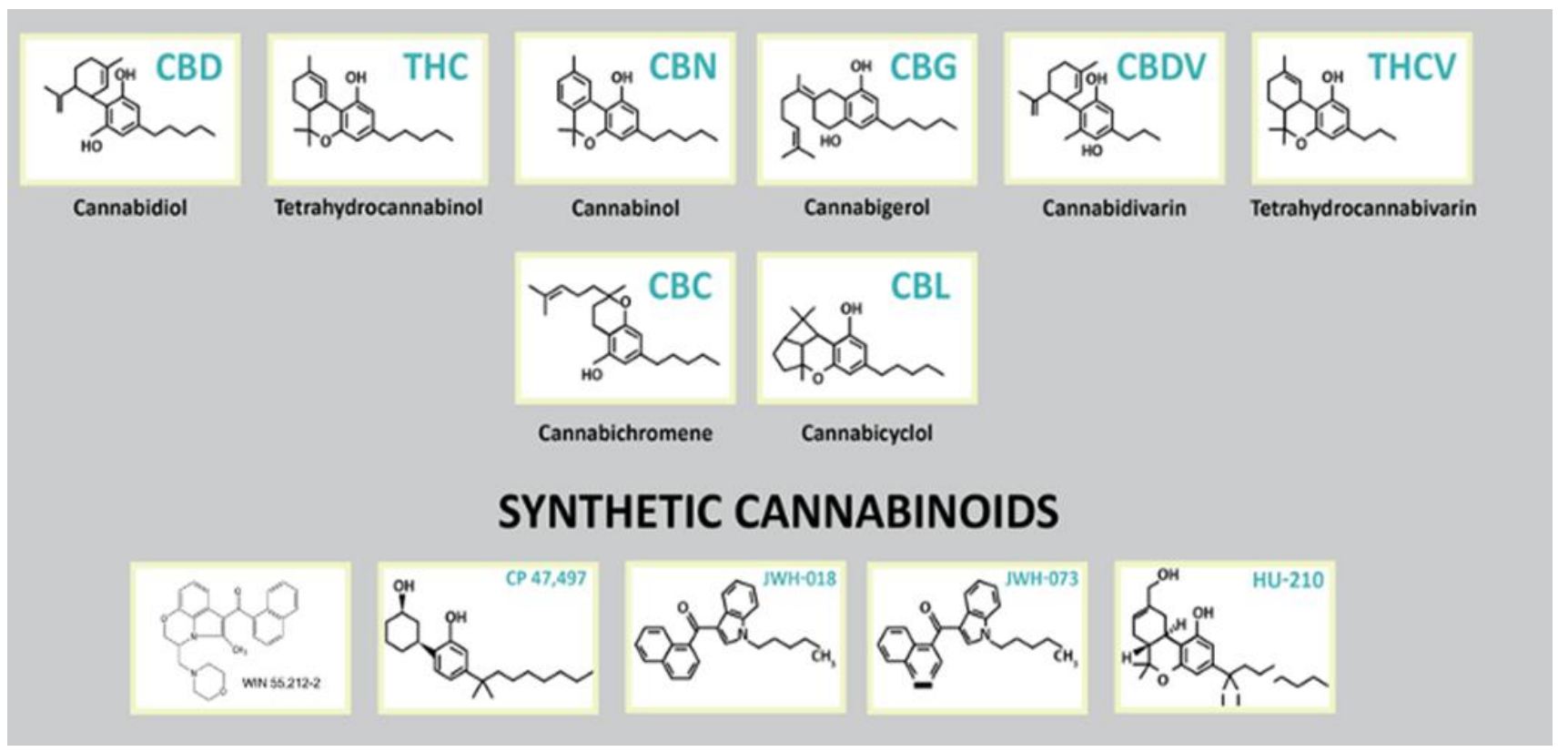

Figure 1: Structural formulas of cannabinoids

Both subtypes of THC are the main and most widely studied psychoactive component of cannabis. Other than being responsible for the euphoric 'high' that characterizes cannabis intoxication, it has shown promise in the treatment of epilepsy, chronic pain, nausea, and muscle spasticity ${ }^{[8]}$. It breaks down to produce cannabidiol (CBD) and cannabinol (CBN), the by-products that were believed to be responsible for the psychoactive features until the 1960 s, when they were originally isolated and synthesized ${ }^{[9]}$.

The biological actions of THC are mediated through its interaction with the endocannabinoid apparatus, which is composed of two cannabinoid receptors-CB1 and CB2-as well as endocannabinoid ligands like anandamide and 2arachidonoylglycerol. THC is a partial agonist of both CB1 and $\mathrm{CB} 2$ receptors but has a high affinity for $\mathrm{CB} 1$. The $\mathrm{CB} 1$ receptor is most densely present in the central nervous system (CNS), especially in the areas affecting movement and motor coordination (cerebellum, basal ganglia, and substantia nigra), complex cognitive functions and attention (cerebral cortex), and emotions and long-term memory (amygdala and hippocampus). CB1 receptors are involved in reducing cellular activity and interfering with the release of various neurotransmitters like GABA, glutamate, dopamine, and acetylcholine, thereby preventing CNS injury due to over- or under-stimulation ${ }^{[10,11]}$. Additionally, CB1 receptors can also be found in immune cells, endocrine organs, the lungs, the spleen, and parts of the gastrointestinal and genitourinary systems ${ }^{[11]}$. It is through these receptors that THC exerts its unique psychoactive effects in a dose-dependent manner which can lead to either relaxation and euphoria on the one hand or paranoia and anxiety on the other ${ }^{[12]}$. The CB2 receptors are mainly involved in immunomodulation and cytokine activity; a recent study shows their presence in microglial cells as well, albeit in low density ${ }^{[13]}$. THC also targets other receptors outside of CB1 and CB2 and is responsible for the various anti-inflammatory, antispasmodic, and anti-neurodegenerative properties of cannabis ${ }^{[14,15]}$. However, THC has also been associated with significant side effects which include immunosuppression, anxiety, and cholinergic defects ${ }^{[16]}$.

\section{Other Compounds}

Cannabidiolic acid (CBDA) is the most common phytocannabinoid found in fiber-type hemp and the second most commonly studied active compound naturally found in cannabis. It has its own array 
of pharmacological properties including anti-nausea, anti-anxiety, and anti-inflammatory actions ${ }^{[17]}$. It is an important 'entourage compound' in the sense that it decreases the side effects of THC, thereby increasing the safety profile of cannabis extracts ${ }^{[18]}$. In fact, in its physiologically meaningful dosage it binds to neither CB1 nor CB2 receptors, thereby bypassing all the psychoactive actions of THC ${ }^{[19]}$. Incidentally, CBDA blocks the transporter protein for endocannabinoids, which has a high affinity to fatty acids, which in turn prolongs the activation of the CB1 receptor $[20,21]$. CBDA also modulates some other receptors, such as the serotonin (5-hydroxytryptamine-5HT1A) receptor and peroxisome proliferator activated receptor (PPAR-y) ${ }^{[22]}$. It has also shown promise as a potential therapeutic agent in the preclinical models of certain neurological diseases such as epilepsy, neurodegenerative disease, affective disorder, schizophrenia, and central modulation of feeding behavior ${ }^{[23]}$. CBDA has interestingly also shown strong anti-fungal and antibacterial properties, and its role against methicillin-resistant Staphylococcus aureus (MRSA) can have significant implications in the treatment of hospital-acquired infections ${ }^{[24]}$. The potential side effects include a) with standard dosing: drowsiness, lightheadedness, dry mouth, hypotension, and fatigue, and b) at high doses: deranged liver function, diarrhea, vomiting, fever, and somnolence ${ }^{[25,26]}$.

$\mathrm{CBC}$ is the third most studied phytocannabinoid after THC and CBD. It possesses high levels of anti-inflammatory, ${ }^{[27]}$ antibacterial, and antifungal ${ }^{[28]}$ properties in addition to analgesia and sedation ${ }^{[29]}$. It is also a potent inhibitor of anandamide uptake [14]. THC in aged cannabis degrades to form CBN, which has half as much affinity for CB1 and three times as much affinity for CB2. Therefore, it has greater influence over the immune system than it does over the nervous system ${ }^{[30]}$. One study showed CBG as a promising alternative in the treatment of murine colitis, suggesting a potential use for the treatment of inflammatory bowel disease in human subjects ${ }^{[31]}$.

\section{Synthetic Cannabinoids}

Molecules with similar structure to THC have also been synthetically produced and approved for use in palliative care especially for patients suffering from AIDS and nausea and vomiting associated with chemotherapy. While both the molecules work as agonists on CB1 and CB2 receptors, Nabilone has twice as affinity. Dronabinol and Nabilone are licenced for use in the US, the Netherlands, Germany, Austria, and Croatia ${ }^{[32]}$. An important distinction has to be made from a new unregulated class of new psychoactive substances (NPS) which are also sold under the misnomer of synthetic cannabinoids (K2/spice) but are separate classes of drugs with different mechanisms of action.

\section{Endocannabinoids and Endocannabinoid Receptors (CB1 and CB2)}

The discovery of preexistent cannabinoid receptors in mammalian cells led to speculation about the presence in vivo of endogenous ligands for said receptors. These suspicions were confirmed by Devane et al. ${ }^{[33]}$ in their 1992 study, where they isolated a lipid called arachidonoyl ethanolamide from the porcine brain which mimicked the behavioral action of THC when injected into rodents. Named anandamide (AEA), after the Sanskrit term "ananda" which means pleasure, this isolate has partial or full agonist activity towards the $\mathrm{CB} 1$ receptors, depending on the tissue and the biological activity measured. Although it binds to the CB2 receptors as well, it either has a very low efficacy or may even act as an antagonist ${ }^{[34]}$. It is synthesized in vivo through the hydrolysis of a membrane lipid precursor N-arachidonoyl phosphatidylethanolamine (NAPE) by phospholipase D (PLD) ${ }^{[35]}$.

Three years after the study by Devane et al., another endocannabinoid, 2-arachidonoylglycerol [2AG], was isolated independently by Mechoulam et al. ${ }^{[36]}$ and Sugiura et al ${ }^{[37]}$. It is synthesized from diacylglycerol (DAG) by DAG lipase selective for the sn-1 position. The baseline levels of $2 \mathrm{AG}$ in the brain are approximately twice that of anandamide, but surprisingly, it is only the latter that demonstrates significantly detectable levels in the extracellular space in response to an extraneous stimulus ${ }^{[38]}$. The reason for this discrepancy has not yet been adequately explored and warrants further study. Figure 2 provides further information regarding the endocannabinoid system and $\mathrm{CB} 1 / \mathrm{CB} 2$ receptors.

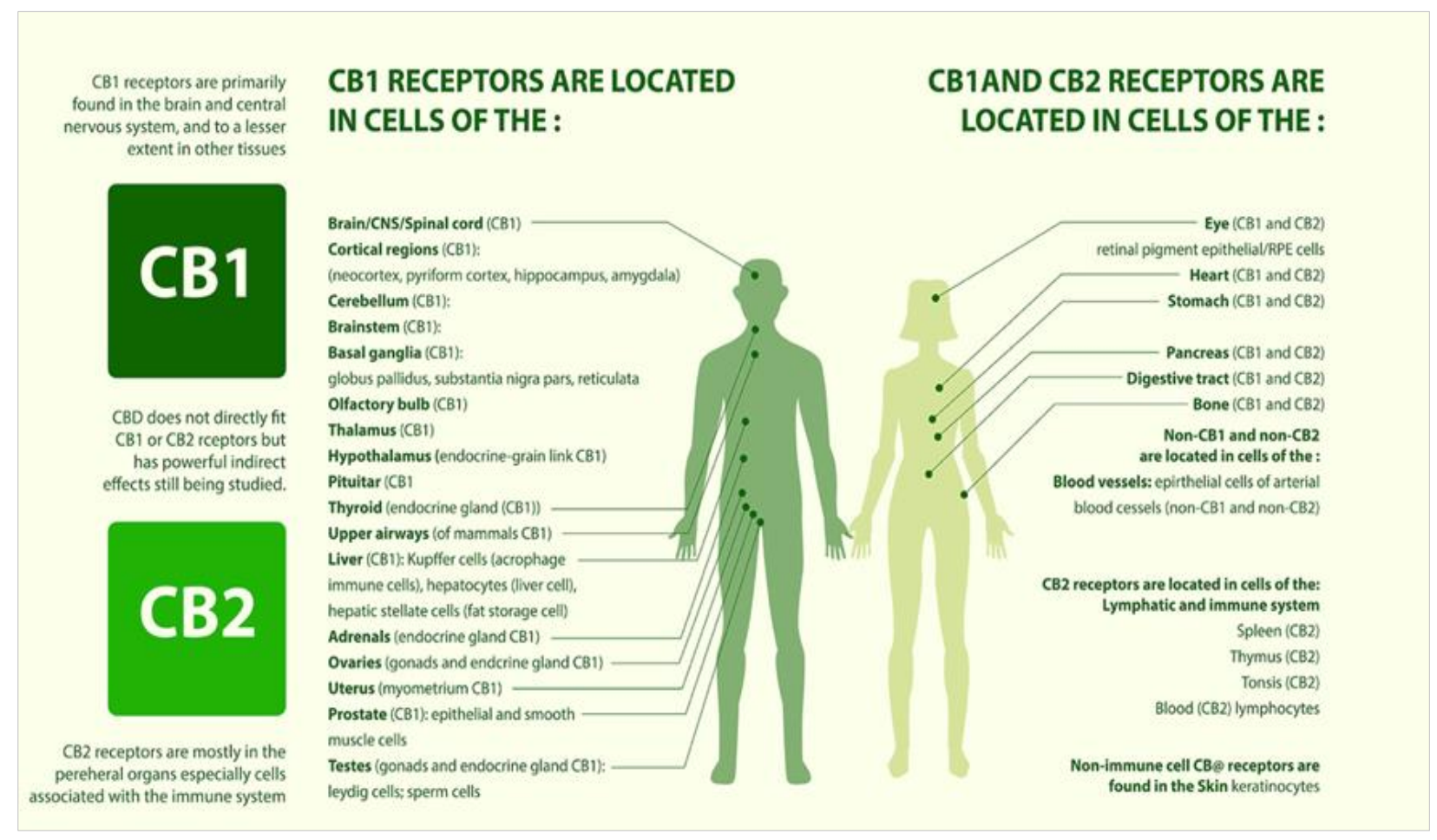

Figure 2: CB1 and CB2 receptors overview 
Significant strides have been taken in the study of endocannabinoids and their role in retrograde transmission ${ }^{[39]}$ as well as their mechanism of release. It was previously believed that, instead of being stored in vesicles, they were generated on an 'ondemand' basis owing to their lipid nature, not dissimilar to prostanoids ${ }^{[40,41,42,43]}$. However, this theory has since been reviewed, after the discovery of AEA storage in lipid droplets (adiposomes) and their association with intracellular transporters [44]. These transporters are responsible for intracellular transport of AEA to different cell organelles such as the nucleus for binding to
PPARs; the endoplasmic reticulum for fatty acid amide hydrolase (FAAH) dependent degradation; adiposomes for storage, oxidation, or degradation; mitochondria for oxidation; and lysosomes for degradation ${ }^{[44,45]}$.

The CB1 and CB2 receptors belong to the family of Gprotein coupled receptors (GPCRs) which further inhibit adenylate cyclase activity ${ }^{[46,47]}$. This failed conversion of adenosine triphosphate (ATP) to cyclic adenosine monophosphate (cAMP) in turn leads to activation of protein kinase A (PKA). Figure 3 demonstrates the mechanism of $\mathrm{CB} 1$ activation.

\section{Cannabinoids}

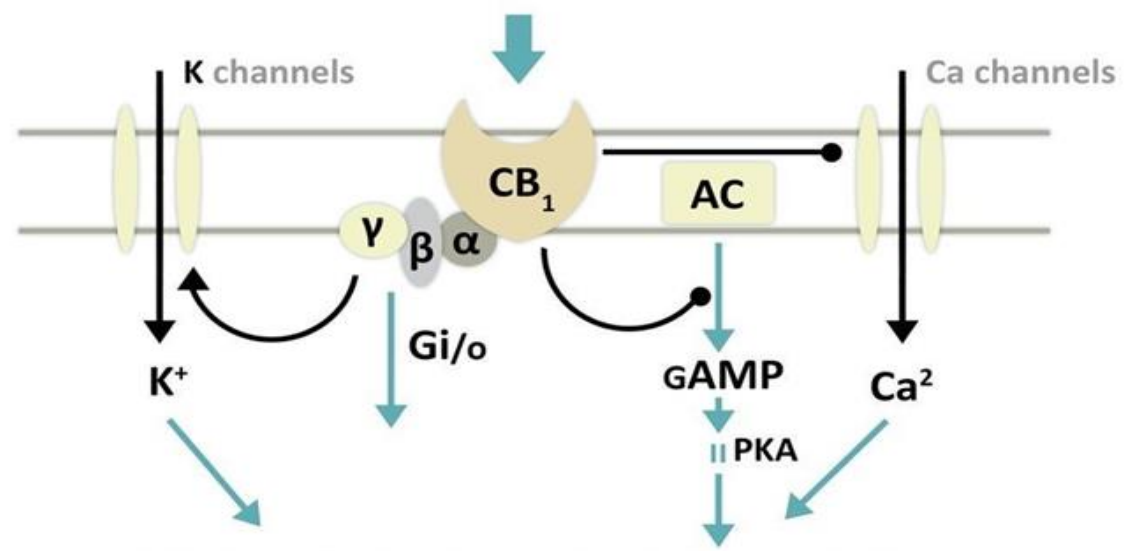

DIRECT \& INDIRECT PHARMACOLOGICAL EFFECTS

Figure 3: Activation of the cannabinoid 1 receptor (CB1) receptors in the central nervous system

Activation of $\mathrm{CB} 1$ and $\mathrm{CB} 2$ receptors leads to downstream activation of all mitogen-activated protein kinase (MAPK), p44/42, p38, and c-JUN amino terminal kinase, which in turn regulates nuclear transcription factors. The activation of these factors is linked to ion channel regulation, which involves activation of potassium channels and inhibition of calcium channels ${ }^{[48]}$. Table 1 summarizes the key points of the endocannabinoid system.

Table 1: Overview of the endocannabinoid system

\begin{tabular}{|c|c|c|c|c|c|}
\hline $\begin{array}{l}\text { Receptor } \\
\text { subtype }\end{array}$ & Location & $\begin{array}{l}\text { Complete } \\
\text { agonist }\end{array}$ & $\begin{array}{l}\text { Partial } \\
\text { agonist }\end{array}$ & Antagonist & Function /Effect \\
\hline CB1 & $\begin{array}{l}\text { Brain } \\
\text { Adipocytes } \\
\text { Endocrine cells } \\
\text { Leukocytes } \\
\text { Heart } \\
\text { Spleen } \\
\text { Genitourinary system } \\
\text { Gastrointestinal } \\
\text { system }\end{array}$ & $\begin{array}{l}\text { 2-AG } \\
\text { Anandamide }\end{array}$ & $\begin{array}{l}\text { THC } \\
\text { (6 times } \\
\text { more } \\
\text { affinity to } \\
\text { CB1 than } \\
\text { CB2) }\end{array}$ & $\begin{array}{l}\text { AM251 } \\
\text { SR141716 } \\
\text { Tetrahydrocannabiv } \\
\text { arin (THCV) } \\
\text { CBD (Inhibits the } \\
\text { effect of the agonists } \\
\text { via negative } \\
\text { allosteric } \\
\text { modulation of the } \\
\text { CB1Rs) }\end{array}$ & $\begin{array}{l}\text { 1.Appetite regulation }{ }^{[49]} \\
\text { 2. Peripheral energy metabolism }{ }^{[50,51]} \\
\text { 3. Analgesia, anti-inflammatory action }{ }^{[52,53]} \\
\text { 4. Neuroprotection }{ }^{[54,55]} \\
\text { 5. Mood regulation and psychosis }{ }^{[56,57]} \\
\text { 6. Antiemesis }{ }^{[58,59]} \\
\text { 7. Sleep }{ }^{[60]} \\
\text { 8. Drug dependence and alcohol disorder }{ }^{[61]} \\
\text { 9.Bradycardia and vasodilation }{ }^{[62,63]} \\
\text { 10. Bronchoconstriction }{ }^{[64,65]} \\
\text { 11. Decreased intraocular pressure } \\
\text { 12. Decreased GI motility } \\
{ }^{[67,68]} \\
\text { 13. Systemic and portal hypotension and } \\
\text { vasodilation in chronic liver cirrhosis }{ }^{[69,70]} \\
\text { 14. Fetal loss and pregnancy failure } \\
{[71,72,73]}\end{array}$ \\
\hline CB2 & $\begin{array}{l}\text { Hematopoietic cells } \\
\text { Brain Bone } \\
\text { Nonparenchymal cells } \\
\text { of the cirrhotic liver } \\
\text { Pancreas }\end{array}$ & $\begin{array}{l}\text { Cannabinolic } \\
\text { acid }(\mathrm{CBN}) \\
\text { Beta } \\
\text { caryophyllene }\end{array}$ & THC & & $\begin{array}{l}\text { 1.Analgesia and anti-inflammatory action } \\
{[13,74,75,76]} \\
\text { 2. Bronchodilation }{ }^{[77]} \\
\text { 3. Antitumor responses }{ }^{[78]} \\
\text { 4. Decreased bone density }{ }^{[79]}\end{array}$ \\
\hline
\end{tabular}




\section{Terpenes: Sedative and Antidepressant Effects}

Terpenes influence the odor and flavor of the different cannabis strains. With more than 200 molecules identified so far in cannabis alone, they are the largest group of phytochemicals ${ }^{[80,81]}$. Figure 4 summarizes most common terpenes discussed in literature. These compounds are pharmacologically versatile and can easily cross the blood-brain barrier ${ }^{[82]}$ due to their lipophilic nature, a feature that allows them to interact with cell membranes as well. Additionally, they can interact with neurotransmitter receptors, odorant G-protein coupled receptors, neuronal and muscle ion channels, and the second messenger systems ${ }^{[83,84]}$. Although the terpenes have a wide repertoire in terms of clinical application, only their sedative and antidepressant effects will be summarized here.

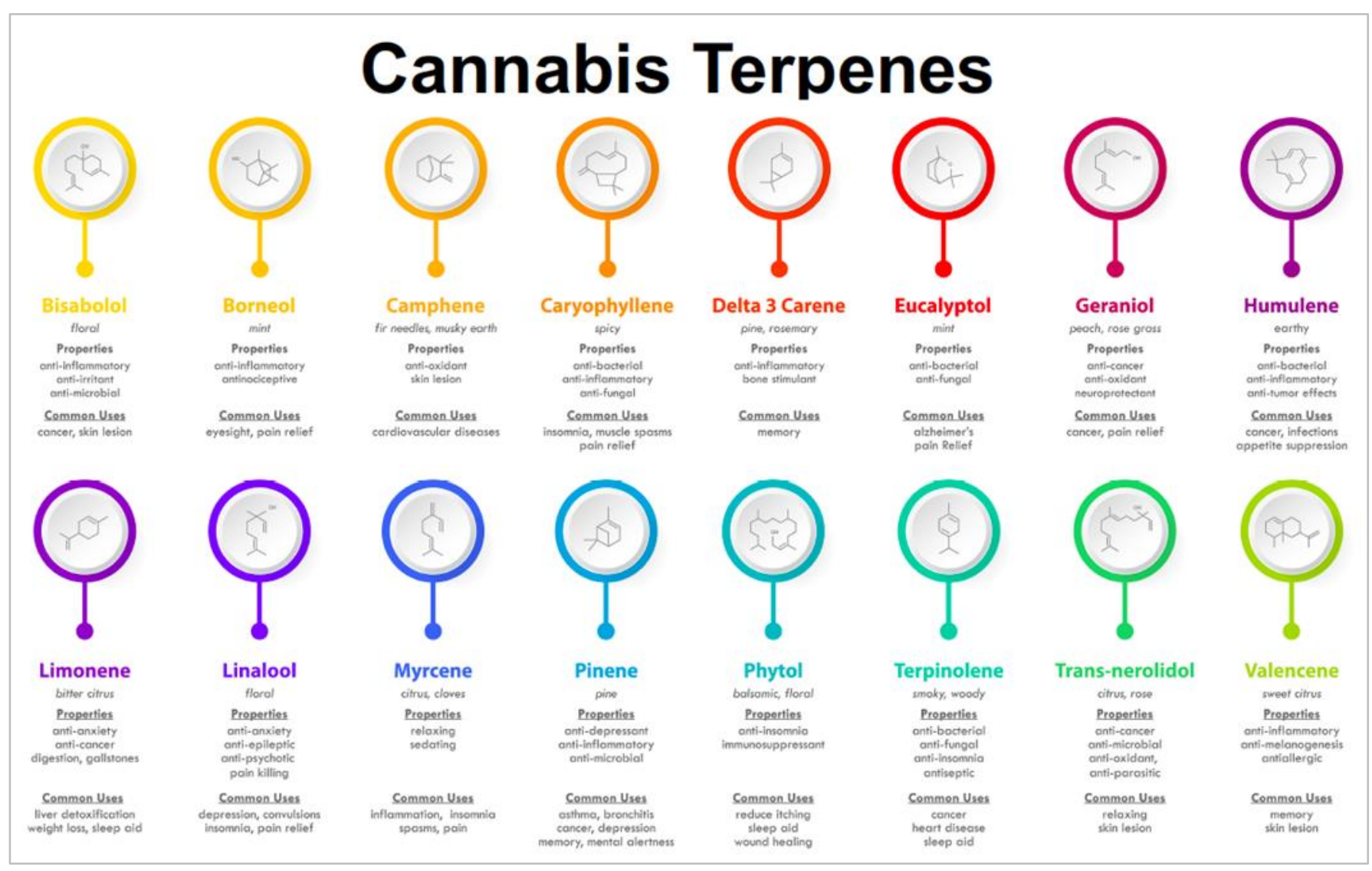

Figure 4: Common cannabis terpenes and their effects

The most widely described terpene in the literature so far is Dlimonene, which has been shown to exhibit significant antidepressant, anti-cancer, and immunostimulant properties in human subjects ${ }^{[85]}$.

Another potent monoterpene found in cannabis is betamyrcene, which has been shown to exhibit sedative properties in mice models ${ }^{[86]}$. It is commonly employed in Germany as a sleep aid ${ }^{[87]}$, an effect that implies its involvement in the "couch-lock phenomenon' commonly observed with cannabis intoxication.

Linalool, a monoterpene alcohol commonly associated with Lavandula angustifolia, has shown similar efficacy in terms of anxiolytic and psychogenic profile ${ }^{[88]}$. There are limited data to assess the efficacy of phytocannabinoid-terpenoid synergy in the treatment of depression and insomnia, and the topic warrants further exploration. In addition to the study conducted by Komori et al. ${ }^{[85]}$, a study conducted in mice models showed olfactory system neurogenesis in response to enriched odor [89]. Theoretically, this model can be applied to the treatment of depression based on plasticity models ${ }^{[90]}$. Further clinical trials are therefore required to accurately assess the therapeutic action of terpenes as antidepressants.

The sedative effects of phytocannabinoids can be similarly enhanced when combined with terpenes like linalool and myrcene. This is because, in addition to providing a hypnotic effect, cannabis compounds have been shown to decrease the symptoms that prevent a restful sleep ${ }^{[91]}$.

\section{Cannabis indica vs. Cannabis sativa}

Cannabis can be split into two main subspecies: Cannabis indica and Cannabis sativa. The two are frequently hybrid but can generally be differentiated by the size of the plants and the color of the leaves. Cannabis indica plants are short and have broad, dark green leaves that contain higher levels of cannabidiol (CBD). Cannabis sativa-dominant plants have higher THC content and appear taller, with thin leaves that are a pale green color. THC and $\mathrm{CBD}$, the two elements of cannabis that are arguably the most talked about, each have unique effects on the body. THC has many psychoactive pharmacologic properties that create the feeling of being 'high'. For people with problems sleeping, depression, or pain, cannabis with high THC content may be beneficial. CBD has the ability to affect one's mood and can also help with anxiety and psychosis. Despite this calming effect, however, in small, monitored doses, CBD can also be a stimulant ${ }^{[92]}$.

It is important to distinguish between the indica and sativa strains as well as the THC to CBD ratio. Small studies and anecdotal evidence classify sativa-dominant strains as energetic and uplifting, making users feel more focused and productive, whereas indica-dominant strains are found to be grounding and calming, useful for pain relief, relaxation, appetite stimulation, and as a sleep aid ${ }^{[93,94]}$. Making a clear distinction is difficult due to the many mixtures of strains and it can be challenging for someone new to the field to be aware of which is best suited for them. Figure 5 summarizes the effects of two main cannabis strains. 


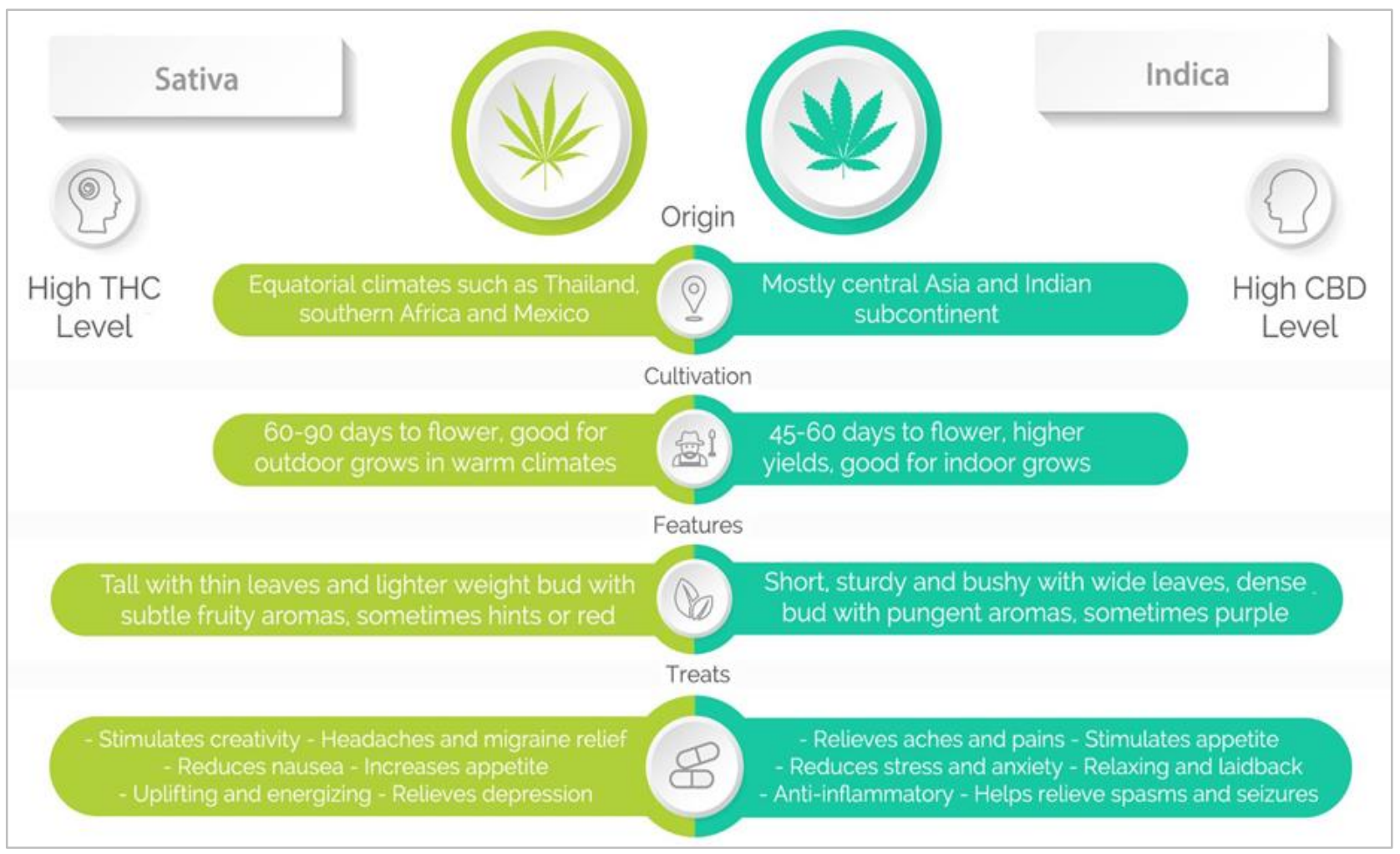

Figure 5: Overview of main cannabis strains

\section{Role of Brain-Derived Neurotrophic Factor (BDNF)}

Brain-derived neurotrophic factor (BDNF) is abundant in the brain and is found in both human serum and plasma in measurable concentrations. BDNF is able to influence the early steps of postnatal neurogenesis, such as cell-fate determination, cell proliferation, and neuronal differentiation of subventricular zone (SVZ) and dentate gyrus (DG) cultures ${ }^{[95]}$. BDNF also plays a vital role in ensuring that neural plasticity is achieved in the brain for it to function effectively. Neural plasticity is a quality of the brain that enables it to reorganize synaptic connections, especially in response to learning or experience, or following injury ${ }^{[96]}$. When an individual is depressed, they are likely to experience lower levels of BDNF ${ }^{[97]}$. The role of BDNF in depression has been established earlier since it acts as a link between the antidepressants, neuroplastic alterations in brain structure and resolution of depression ${ }^{[98]}$. The most widely accepted hypothesis, which focuses on antidepressants restoring the compromised neurotransmission in mainly noradrenergic and serotonergic systems, has dominated our understanding of antidepressant action [99].

Preclinical studies suggest that cannabinoids modulate BDNF activity, but the precise mechanism underlying such effects is not clearly established ${ }^{[97]}$. Cannabidiol has been found to have antidepressant-like effects through increased BDNF signaling in the prefrontal cortex. However, studies have not been conclusive about the use of marijuana as an effective antidepressant. The longterm effects of the use of cannabis and its dependence have been highlighted in most studies, and it is believed to have a negative impact on BDNF metabolism. Findings suggest that when marijuana use escalates, the BDNF pathway becomes more deregulated. Moreover, the age of marijuana use onset influences the magnitude of these changes ${ }^{[100]}$.

Though BDNF has been widely studied for its ability to support neuronal development and plasticity, other less beneficial effects have been described. Data from animal models indicate, albeit with some exceptions, that BDNF contributes to the enduring synaptic plasticity that underlies drug addiction ${ }^{[101]}$. Given that some cannabinoids can influence BDNF activity, and considering BDNF's critical role in controlling brain development, cognitive processes, and neuroplasticity, it is surprising that very little research on BDNF has been done in this context ${ }^{[102]}$. The few studies examining the relationship between BDNF and marijuana in healthy humans have been inconclusive. They were mostly cross-sectional and performed on adults, and applying their conclusions to other age groups would be flawed, as marijuana leads to different neurochemical effects in adolescence and during adulthood. In addition, serum was used to measure BDNF levels, which has led to questionable conclusions ${ }^{[103]}$.

\section{Anti-inflammatory Properties of Cannabis}

Research suggests that CBD acts as a weak agonist on the CB2 receptors ${ }^{[104]}$, but it may also bind to the same receptor-binding site as an agonist and produce the opposite effect by suppressing spontaneous CB2 receptor signaling ${ }^{[105]}$. Activation of CB2 receptors can decrease immune cell migration and trigger antiinflammatory biochemical cascades ${ }^{[106]}$. Figure 6 provides additional information regarding the role of cannabinoids in regulation of immune processes. 


\section{The Endocannabinoid System}

Endocannabinoids, as typical bioactive lipids, have a short half-life and appear to act in an autocrine and paracrine fashion. Their immediate effective action on immune function may be at localized sites in the periphery and within the central nervous system. It is speculated that endocannabinoids play an important role in maintaining the overall "fine-tuning" of the immune homeostatic balance within the host.
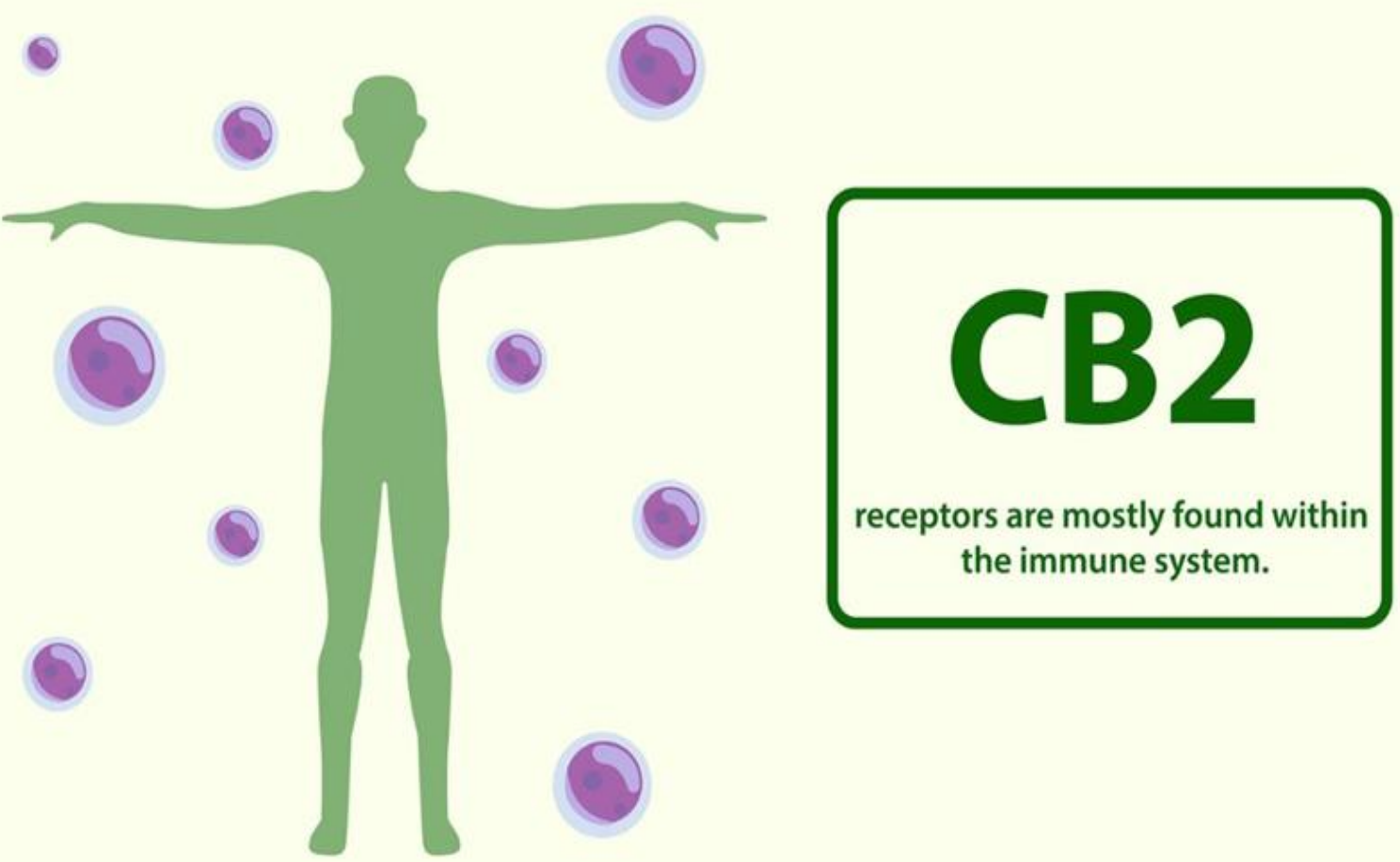

Endocannabinoids are believed to control immune functions and play a role in immune homeostasis. Immune cells express both CB1 and CB2 receptors, secrete endocannabinoids and have functional cannabinoid transport and breakdown mechanisms. There is a large body of data that supports a functional relevance for 2-arachidonoylglycerol (2-AG) as acting through the cannabinoid receptor type 2 (CB2R) to inhibit migratory activities for a diverse array of immune cell types. However, unequivocal data that supports a functional linkage of anandamide (AEA) to a cannabinoid receptor in immune modulation remains to be obtained.
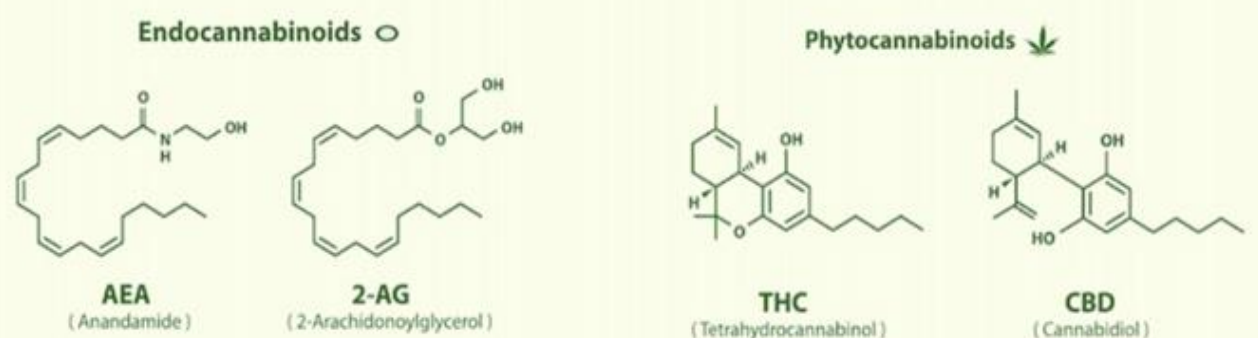

Figure 6: Endocannabinoids and the Immune System

It is proposed that the endocannabinoid system, which includes Gprotein coupled receptors, may be responsible for the therapeutic modulation of oxidative stress. Pre-clinical studies show that CBD may reduce oxidative conditions by preventing the formation of superoxide radicals, which are mainly generated by xanthine oxidase (XO) and NADPH oxidase (NOX1 and NOX4). CBD can also affect the redox balance by modifying the level and activity of oxidants and antioxidants. It works in an antioxidant effect by interrupting the formation of free radical chain reactions and transforming them into less active forms. The direct reduction of oxidant levels allows CBD to better modify the redox balance by balancing the oxidative stress induced in the body ${ }^{[107]}$.

In 1994, a survey was conducted on 112 patients from the United States and the United Kingdom who had been diagnosed with multiple sclerosis (MS). All of them were using cannabis to self-medicate. More than 90 percent of patients reported improvement regarding their symptoms of spasticity, pain, tremor, and depression. This finding was congruent with eight different clinical studies where MS patients also reported symptom alleviation from the use of cannabinoids ${ }^{[108]}$. It was noted that cannabinoids are useful in treating multiple sclerosis symptoms due to their immunosuppressive properties that limit $\mathrm{T}$ cell reactivity and proinflammatory cytokine release, thus contributing to the protection of myelin and the integrity of the blood-brain barrier ${ }^{[108]}$. Similar mechanisms may apply to other inflammatory conditions such as colitis, hepatitis, rheumatoid arthritis, and certain psychiatric conditions with underlying inflammatory components, but the current data are insufficient to substantiate such claims. Figure 7 summarizes some of the established antiinflammatory effects of cannabinoids and their role in mood regulation. 


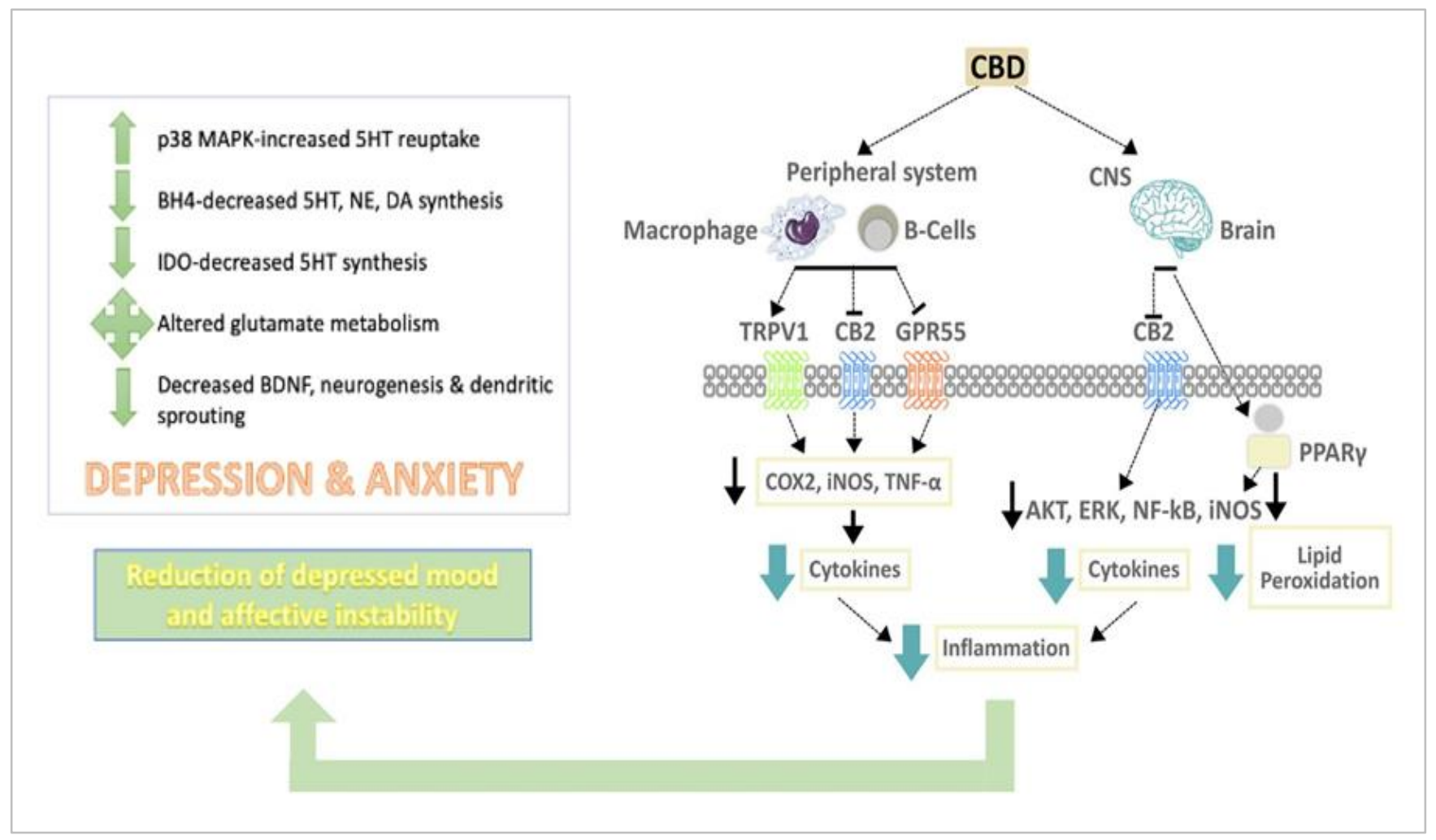

Figure 7: Role of cannabinoids in inflammation and affective instability

\section{Clinical Aspects of Cannabis Use in Palliative Care}

Due to its various therapeutic properties, cannabis has started to play a big role in palliative care. Medicinal cannabis will probably not be considered as a first-line agent for palliative care management of pain, nausea, and other symptoms, however, it can play an important role as an adjuvant, complementary therapy.

There has been a considerable increase in cannabis use to alleviate symptoms in cancer and hospice patients ${ }^{[109]}$. Regarding the effectiveness of medical cannabis, the largest analysis to date was issued in 1999 by a group of independent scientists commissioned by the White House and appointed by the Institute of Medicine (IOM). It was determined that scientific evidence suggests potential therapeutic use of cannabinoids, primarily THC, for pain, nausea, vomiting, and appetite stimulation, which are common among those seeking palliative care. However, these benefits were limited by the harmful effects of smoking. It was thus recommended that the substance be given under close supervision when patients did not respond to other therapies. The report also found that some patients may benefit from its psychological effects while others may not, and there was no evidence that medical marijuana would increase the illicit use of other substances ${ }^{[110]}$.

An extensive review of more than 10,000 scientific abstracts on the health effects of cannabis determined that it can be used therapeutically for chronic pain, chemotherapy-induced nausea and vomiting, and multiple sclerosis-associated spasticity [111]. Moreover, cannabis consumption for recreational purposes may enhance the quality of life and psychological distress in individuals with recently diagnosed tumors ${ }^{[112]}$. Nonetheless, a review of nine randomized controlled trials on patients with latestage HIV, terminal cancer, and Alzheimer's found little conclusive evidence about the effects of cannabis products on appetite, pain, and overall quality of life in this population ${ }^{[113]}$.

Due to the lack of consistent evidence and the risk of mental health problems associated with their use, current guidelines recommend prescribing cannabinoids in a palliative care setting only when other treatments have failed ${ }^{[114]}$. Integrating these products into palliative psychiatry has been a difficult road because there is poor clinical knowledge, lack of clinical trials, and an overall stigma attached to these products ${ }^{[1]}$.

Interestingly, an Israeli study on cannabis use in more than 3,000 cancer patients showed significant improvement in symptoms such as sleeping difficulty, fatigue, anxiety, and depression. One of the major points was that only 18.7 percent of participants reported a good quality of life at the start of the study; however, at 6 months, 69.5 percent reported a good quality of life. During these 6 months, 36 percent of patients discontinued their use of opioids and less than 20 percent stopped their cannabis treatment ${ }^{[1]}$. Cannabis offers a wide range of possible bioactive advantages that appear to exceed the dangers in various scenarios [115].

\section{Depression}

The body of knowledge concerning the use of cannabis for the treatment of depression continues to increase, with some studies being directed towards understanding how cannabis may improve the quality of life for depressed patients, especially those suffering from cancer ${ }^{[116]}$. While some researchers have tended to state that cannabis may cause the onset of depression or worsening of its symptoms, some studies have shown that cannabis may be used to remedy depression. Feingold and Weinstein ${ }^{[117]}$ propose that marijuana consumption and depression may be more prevalent in males during youth and early adulthood and less prevalent in women in adulthood.

A meta-analysis of studies including patients 18 years or older using pharmaceutical-grade $\mathrm{THC}$ or $\mathrm{CBD}$, or medical cannabis assessed the effects of these cannabinoids on mental disorders. The meta-analysis found that the use of pharmaceutical grade $\mathrm{THC} \pm \mathrm{CBD}$ did not significantly change symptoms of depression. It is worth noting that the quality of evidence supporting this conclusion was rated "very low" and that none of 
the studies included patients with a primary diagnosis of depression ${ }^{[118]}$.

There is support for a possible genetic link leading to the combination of marijuana addiction and severe depression; specifically, serotonin (5-HT) may facilitate such a relationship and evidence exists for particular risk alleles for cannabis addiction ${ }^{[119]}$. Research also revealed the existence of at least three genetic variants associated with persistent cannabis dependence, schizophrenia, and major depressive disorder.
Preclinical data also suggest that alterations in the endocannabinoid system are associated with depression [120] Specifically, the data suggest that stimulation of the endocannabinoid system via $\mathrm{CB} 1$ receptors may explain an antidepressant-like effect in some animal models of depression ${ }^{[120]}$. Nevertheless, using marijuana as an antidepressant is still under investigation, and there is insufficient data to support the practice. Table 2 summarizes most recent data regarding the use of cannabinoid agents in depressive disorders.

Table 2: Use of cannabinoid agents in depression

\begin{tabular}{|c|c|c|c|}
\hline \multicolumn{4}{|c|}{ Depression } \\
\hline Cannabinoid agent & Associated condition & Reported effects & References \\
\hline \multirow[t]{2}{*}{$\mathrm{THC} \pm \mathrm{CBD}$} & $\begin{array}{l}\text { Chronic non-cancer } \\
\text { pain }\end{array}$ & No significant improvement in symptoms of depression. & Black, N., et al. (2019) ${ }^{[118]}$ \\
\hline & Multiple sclerosis & No significant improvement in symptoms of depression. & Black, N., et al. (2019) ${ }^{[118]}$ \\
\hline$\Delta^{9}-\mathrm{THC}$ & $\begin{array}{l}\text { Depression-like } \\
\text { behavior in mice }\end{array}$ & $\begin{array}{l}\text { A U-shaped dose response was observed in both the forced } \\
\text { swim test (FST) and the tail suspension test (TST), with } \\
\text { the nadir at a } 2.5 \mathrm{mg} / \mathrm{kg} \text { dose representing a statistically } \\
\text { significant antidepressant-like effect. }\end{array}$ & $\begin{array}{l}\text { El-Alfy, A. T., et al. (2010) } \\
\text { [121]. }\end{array}$ \\
\hline Dronabinol & Depression & $\begin{array}{l}\text { Antidepressive effect suggested. Study was withdrawn and } \\
\text { no participants were recruited due to high drug cost. }\end{array}$ & Forester, B. P. (2019) ${ }^{\lfloor 122]}$ \\
\hline $\begin{array}{l}\text { Synthetic } \\
\text { cannabinoids }\end{array}$ & Substance use disorder & $\begin{array}{l}\text { Depressive symptoms measured with the Beck Depressive } \\
\text { Inventory were significantly higher in patients who } \\
\text { predominantly used synthetic cannabinoids than in those } \\
\text { who used predominantly marijuana. }\end{array}$ & $\begin{array}{l}\text { Görgülü, S. A., \& Sevindik, } \\
\text { C. S. (2020). }{ }^{[123]}\end{array}$ \\
\hline \multirow[t]{2}{*}{ Nabiximols } & $\begin{array}{l}\text { Multiple sclerosis with } \\
\text { inadequately managed } \\
\text { spasticity }\end{array}$ & $\begin{array}{l}\text { No significant effect of nabiximols on depression or } \\
\text { suicidality, as measured by the Beck Depressive Inventory- } \\
\text { II. }\end{array}$ & $\begin{array}{l}\text { DeLuca, J., Berwaerts, J., \& } \\
\text { Wagner, J. (2021). }{ }^{[124]}\end{array}$ \\
\hline & Cannabis withdrawal & $\begin{array}{l}\text { Administration of nabiximols resulted in a statistically } \\
\text { significant decrease in depression. }\end{array}$ & $\begin{array}{l}\text { Allsop, D. J., et al. (2014). } \\
\text { [125] }\end{array}$ \\
\hline
\end{tabular}

\section{Anxiety disorders}

In anxiety disorders, the mechanism thought to help anxiety is through the activation of the serotonergic 5-HT1A receptor as well as the $\mathrm{CB} 1$ receptor ${ }^{[126]}$. When $\mathrm{CB} 1$ is activated, there is an enhancement of fear extinction, reconsolidation blockade, and prevention of long-term anxiogenic stress. Two clinical studies analyzed the effects of CBD in psychiatric patients who have been diagnosed with pathological anxiety. It was found that CBD significantly reduced anxiety, cognitive impairment, and altered speech performance ${ }^{[127]}$. Analysis of another study found that pharmaceutical grade THC \pm CBD led to a statistically significant decrease in anxiety. Again, the quality of evidence was rated "very low," and no studies included participants with a primary diagnosis of an anxiety disorder. The analysis for THC \pm CBD's effect on anxiety excluded three studies due to incomplete data reporting, but the researchers believe that had this data been included, the benefit of pharmaceutical grade THC \pm CBD would no longer be statistically significant ${ }^{[118]}$. Table 3 provides additional information regarding the anxiolytic effects of cannabinoid agents.

Table 3: Use of cannabinoid agents in anxiety

\begin{tabular}{|c|c|c|c|}
\hline \multicolumn{4}{|c|}{ Anxiety } \\
\hline Cannabinoid agent & Associated conditions & Reported effects & References \\
\hline \multirow[t]{2}{*}{$\mathrm{THC} \pm \mathrm{CBD}$} & $\begin{array}{l}\text { Chronic non-cancer } \\
\text { pain }\end{array}$ & Statistically significant decrease in anxiety. & Black, N., et al. (2019). \\
\hline & Multiple sclerosis & Statistically significant decrease in anxiety. & Black, N., et al. (2019). ${ }^{[118]}$ \\
\hline \multirow[t]{3}{*}{$\mathrm{CBD}+\mathrm{THC}$} & $\begin{array}{l}\text { Autism spectrum } \\
\text { disorder }\end{array}$ & $\begin{array}{l}\text { Nearly half of the patients showed improvement in anxiety } \\
\text { symptoms. }\end{array}$ & Khan, R., et al. (2020). ${ }^{\lceil 28]}$ \\
\hline & Multiple sclerosis & Treatment did not increase or decrease anxiety. & $\begin{array}{l}\text { Garakani, A., et al. (2020). } \\
\text { [129] }\end{array}$ \\
\hline & Huntington disease & Treatment resulted in no significant change in anxiety. & $\begin{array}{l}\text { Garakani, A., et al. } \\
(2020){ }^{[129]}\end{array}$ \\
\hline \multirow[t]{2}{*}{$\Delta^{9}-\mathrm{THC}$} & Tourette syndrome & $\begin{array}{l}\text { Obsessive-compulsive behavior worsened after } \\
\text { administration of THC. There was no statistically significant } \\
\text { difference in anxiety scores, but there was a trend of } \\
\text { increased phobic anxiety. }\end{array}$ & $\begin{array}{l}\text { Garakani, A., et al. (2020). } \\
\text { [129] }\end{array}$ \\
\hline & Anxiety & $\begin{array}{l}\text { Many studies have shown that CB1 agonists have a bi- } \\
\text { modal effect on anxiety-at low doses it is anxiolytic and at } \\
\text { higher doses it is anxiogenic. }\end{array}$ & $\begin{array}{l}\text { Tambaro, S., \& Bortolato, } \\
\text { M. (2012). }{ }^{[130]}\end{array}$ \\
\hline
\end{tabular}




\begin{tabular}{|c|c|c|c|}
\hline \multirow[t]{4}{*}{ CBD } & Anxiety & $\begin{array}{l}\text { Nearly } 80 \% \text { of patients reported reductions in anxiety based } \\
\text { on the Hamilton Anxiety Rating Scale. }\end{array}$ & Khan, R., et al. (2020). ${ }^{[128]}$ \\
\hline & \multirow[t]{2}{*}{$\begin{array}{l}\text { Social anxiety } \\
\text { disorders }\end{array}$} & $\begin{array}{l}\text { CBD appears to have a bi-modal effect on anxiety-at low } \\
\text { doses it is anxiolytic and at higher doses it is anxiogenic. }\end{array}$ & $\begin{array}{l}\text { Tambaro, S., \& Bortolato, } \\
\text { M. (2012). }{ }^{[130]}\end{array}$ \\
\hline & & $\begin{array}{l}\text { Compared to placebo, pretreatment with CBD resulted in } \\
\text { decreased anxiety, cognitive impairment, and discomfort in } \\
\text { simulated public speaking. }\end{array}$ & Khan, R., et al. (2020). ${ }^{[128]}$ \\
\hline & $\begin{array}{l}\text { Anxiety induced by } \\
\text { high doses of THC }\end{array}$ & $\begin{array}{l}\text { CBD may alter the euphoric and anxiogenic effects of THC. } \\
\text { Some studies have shown that CBD decreases the sensations } \\
\text { induced by THC, while other studies have shown that pre- } \\
\text { treatment with CBD potentiates sensations induced by THC. }\end{array}$ & $\begin{array}{l}\text { Tambaro, S., \& Bortolato, } \\
\text { M. (2012). }\end{array}$ \\
\hline \multirow[t]{2}{*}{ Dronabinol } & Anxiety & $\begin{array}{l}\text { Study was withdrawn and no participants were recruited due } \\
\text { to high drug costs. }\end{array}$ & Forester, B. P. (2019). ${ }^{[122]}$ \\
\hline & Unspecified pain & $\begin{array}{l}\text { No statistically significant changes in anxiety scores were } \\
\text { found. One study reported that some subjects experienced } \\
\text { high anxiety after administration of higher dronabinol doses. }\end{array}$ & $\begin{array}{l}\text { Garakani, A., et al. (2020). } \\
\text { [129] }\end{array}$ \\
\hline \multirow[t]{6}{*}{ Nabilone } & \multirow[t]{2}{*}{ Anxiety } & $\begin{array}{l}\text { Nabilone was significantly more effective than placebo in } \\
\text { decreasing both somatic and psychic anxiety. The study } \\
\text { suggests that single doses of nabilone are minimally } \\
\text { effective and that anxiolytic effects are reached with } \\
\text { prolonged treatment. }\end{array}$ & $\begin{array}{l}\text { Fabre, L. F., \& McLendon, } \\
\text { D. (1981). }{ }^{[131]}\end{array}$ \\
\hline & & $\begin{array}{l}\text { Statistically significant improvement in anxiety in those } \\
\text { treated with nabilone compared to placebo. }\end{array}$ & $\begin{array}{l}\text { Garakani, A., et al. (2020). } \\
\text { [129] }\end{array}$ \\
\hline & Neuropathic pain & Nabilone does not have a significant effect on anxiety. & $\begin{array}{l}\text { Garakani, A., et al. (2020). } \\
\text { [129] }\end{array}$ \\
\hline & $\begin{array}{l}\text { Diabetic peripheral } \\
\text { neuropathy }\end{array}$ & Nabilone reduced anxiety in this population. & $\begin{array}{l}\text { Garakani, A., et al. (2020). } \\
\text { [129] }\end{array}$ \\
\hline & Fibromyalgia & Nabilone reduced anxiety in this population. & $\begin{array}{l}\text { Garakani, A., et al. (2020). } \\
\text { [129] }\end{array}$ \\
\hline & Chronic headache & Nabilone does not have a significant effect on anxiety. & $\begin{array}{l}\text { Garakani, A., et al. (2020). } \\
\text { [129] }\end{array}$ \\
\hline Nabiximols & Tourette syndrome & $\begin{array}{l}\text { Patients experienced improvements in tic frequency and } \\
\text { severity. The author attributes these benefits to the } \\
\text { anxiolytic effects of CBD. }\end{array}$ & Khan, R., et al. (2020). ${ }^{[128]}$ \\
\hline Rimonabant & N/a & $\begin{array}{l}\text { Rimonabant is a CB1 antagonist/inverse agonist. Clinical } \\
\text { trials in Europe found that use of this agent led to a } \\
\text { significant increase in anxiety, depression, and suicidality. }\end{array}$ & $\begin{array}{l}\text { Tambaro, S., \& Bortolato, } \\
\text { M. (2012). }\end{array}$ \\
\hline
\end{tabular}

\section{Psychoactive and Addictive Potential of Cannabis}

It is being researched whether psychoactive features can also be beneficial in palliative care. From cultural use and anecdotal reports through patients and caregivers, it has been suggested that cannabis use leads to euphoria, aversive memory extinction and enhanced sensory effect. It is also associated with temporary dissociative states. These states can create a distancing experience from the pain felt by palliative care patients. Not all patients are comfortable with this feeling, but some may welcome it as it provides an alternative to opioids, which can have serious adverse effects. The induction of a dissociative state can also make practitioners uncomfortable because it may seem like intoxicating the patient; however, it is important for healthcare providers to discuss these experiences with patients and hear from their perspective how it makes them feel ${ }^{[132]}$.

It has been documented in recent literature that the endocannabinoids are involved in mood regulation and that cannabis use can negatively affect the development or progression of mood disorders ${ }^{[133]}$. Among cancer patients, medical cannabis is mostly sought after to relieve symptoms of anxiety and depression. Although there were questionable data of cancer patients experiencing alleviation of these symptoms, many also reported having not only more anxiety but also withdrawal symptoms upon ceasing treatment ${ }^{[134]}$. Furthermore, psychoactive effects such as paranoia and panic attacks have been reported. According to a study done by Gage et al. in 2017, cannabis use was found to have an association with schizophrenia, especially when used at a younger age ${ }^{[135]}$.

While the above-mentioned negative effects predominate in the current literature, there have also been several studies showing improvement in the mood of cancer patients using cannabinoid therapy ${ }^{[136]}$. As can be seen in these conflicting results, further research and education is necessary in order to get more practitioners involved and informed regarding medical cannabis use ${ }^{[136]}$.

Bahorik et al. ${ }^{[137]}$ pointed out that psychiatric disorders such as chronic depression, anxiety disorders, and sleeplessness are prevalent after chemotherapy. Even though there is no scientific evidence to support cannabis use for psychiatric disorders and symptoms throughout cancer treatment, Pergam et al. [138] discovered that a high number of patients do use it for these concerns. Thus, cannabis usage may be linked to self-medication of major mental illnesses and evasion of potentially effective evidence-based treatments for these issues. Based on previous studies regarding cannabis use, it is apparent that dependence and addiction are possible adverse effects that cancer patients could experience. However, Pergam et al. ${ }^{[138]}$ point out that more research is necessary to understand cannabis' function as an option or adjuvant for relieving depression, anxiety, and sleeplessness, as well as other prevalent cancer-related symptoms. 
A study done by Kleckner et al. in 2019 mentioned that when cannabis is used with guideline-based treatment regimens, it exhibits potential benefits that outweigh the risks ${ }^{[133]}$. Another study done regarding addiction in cancer patients also established that, since the goal of palliative care is to limit patient suffering and to improve quality of life, certain medications and treatment modalities for substance use disorders should be taken seriously [139].

\section{Healthcare Providers' Views on Cannabis}

When contemplating the use of medical cannabis in palliative care, the perception and research of experienced healthcare providers should be consulted. Despite inconsistent results about its use in palliative care, many healthcare workers have positive attitudes towards medical cannabis. A study based on a survey of 310 hospice professionals around the United States found that a significant majority of respondents supported access to the drug by hospice patients ${ }^{[140]}$. One of the most attractive aspects of medical cannabis for physicians and patients is its potential to replace opiates, which have a much higher potential for abuse, in the treatment of chronic pain. This is an intriguing alternative, especially in light of the ongoing opioid crisis in the United States ${ }^{[140]}$. In support of this, a 2019 study found that medical cannabis legalization was associated with lower rates of opioid use in both general, chronic opioid use and high-risk opioid use ${ }^{[141]}$.

In 2017, a survey of cancer patients in a major cancer center in Seattle showed that there was a very high rate of cannabis use. At least twenty five percent of the patients reported using cannabis. This survey also showed that many patients were not informed of this therapeutic option by their provider. Conversely, in a survey of 237 U.S. oncologists in 2018, 46 percent recommended cannabinoid-based medicines to their patients and 67 percent viewed these medications as helpful to standard and adjunct pain management ${ }^{[1]}$.

Although there have been many challenges facing the use of cannabis from a therapeutic standpoint, there has also been increased responsiveness by providers to its clinical benefits ${ }^{[142]}$. García-Gutiérrez et al. posit that cannabis may supplement a very limited arsenal in the hands of a palliative care physician due to its comparatively benign side effect profile, which includes no depressing impact on the respiratory tract ${ }^{[142]}$. More comprehensive research on the benefits and risks of cannabis use as well as the efficacy of medical cannabis compared to opioids is still needed.

\section{Drug Interactions}

Cannabinoids may have pharmacokinetic interactions with conventional psychiatric medications. It has been suggested that cannabinoids may affect the activity of CYP P450 ${ }^{[143]}$. For example, CYP2C9, CYP1A1/2, and CYP1B1 are inhibited by 3 major cannabinoids: $\Delta$-tetrahydrocannabinol (THC), cannabidiol (CBD), and cannabinol $(\mathrm{CBN})^{[144]}$. Table 4 summarizes the effects of THC/ CBD on cytochromes.

Table 4: Effects of cannabinoids on the CYP450 system

\begin{tabular}{|c|c|c|c|}
\hline Compound & Cytochrome involved & Mechanism of changes & References \\
\hline THC (non-inhalation) & $\begin{array}{l}\text { CYP2C9, CYP3A4 CYP2D6, CYP2C19, } \\
\text { CYP2B6, and CYP2J2, CYP1A1 }\end{array}$ & $\begin{array}{l}\text { Inhibition } \\
\text { Induction }\end{array}$ & $\begin{array}{l}\text { Rong et al., (2018) })^{[143]} \\
\text { Qian et al., (2019) }\end{array}$ \\
\hline CBD (non-inhalation) & $\begin{array}{l}\text { CYP2C19, CYP3A4/5/7 } \\
\text { CYP2D6, CYP2B6 } \\
\text { CYP2J2 }\end{array}$ & Inhibition & $\begin{array}{l}\text { Rong et al., (2018) } \\
\text { Qian et al., (2019) } \\
\text { Bouquié et al., 2018 }\end{array}$ \\
\hline $\mathrm{CBN}$ & CYP3A, CYP2D6, CYP2C9 & Inhibition & Alsherbiny $(2018)^{[146]}$ \\
\hline Cannabis inhalation & CYP1A1, CYP1A2 & Induction & Rong et al., (2018) \\
\hline
\end{tabular}

There are several clinically important pharmacological interactions between cannabis and antidepressants, but data regarding pharmacokinetics and pharmacodynamics are extremely limited. Cannabis-induced alterations in drug absorption, distribution, metabolism, excretion, and effectiveness are possible in patients with affective disorders, and some psychotropics may have to be given in higher dosages. Table 5 summarizes the effects of cannabinoids on the metabolism of common psychotropic agents.

Table 5: Interactions of cannabinoids and various psychotropic agents (adapted from Ganoci et al., Prog Neuropsychopharmacol Biol Psychiatry 2020; 10(104):110042). ${ }^{[147]}$

\begin{tabular}{|l|l|l|}
\hline Medication & CYP Subtype & Effects of Cannabis \\
\hline Fluoxetine & CYP2D6, CYP2C9 & $\begin{array}{l}\text { Inhibition of CYP2D6, CYP2C9 can lead to supratherapeutic drug level and } \\
\text { unanticipated adverse reactions }\end{array}$ \\
\hline Fluvoxamine & CYP2D6, CYP1A2, P-gp & $\begin{array}{l}\text { Induction of CYP1A2 can cause subtherapeutic drug level or therapeutic failures. } \\
\text { Inhibition of CYP2D6 can lead to supratherapeutic drug level and unanticipated } \\
\text { adverse reactions }\end{array}$ \\
\hline Ventraline & CYP2C19, 2B6 & $\begin{array}{l}\text { Inhibition of CYP2C19, CYP2B6 can lead to supratherapeutic drug level and } \\
\text { unanticipated adverse reactions }\end{array}$ \\
\hline Carbamazepine & CYP3A4/5 & $\begin{array}{l}\text { Inhibition of CYP2C19, CYP3A4/5/7 } \\
\text { CYP2D6 can cause supratherapeutic drug level and unanticipated adverse } \\
\text { reactions (hyperactivation, headache) }\end{array}$ \\
\hline Aripiprazole & CYP2D6, CYP3A4/5, P-gp & $\begin{array}{l}\text { Inhibition of CYP3A4/5 can cause unanticipated adverse reactions and potential } \\
\text { carbamazepine toxicity }\end{array}$ \\
\hline Asenapine & CYP1A2, UGT1A4 & $\begin{array}{l}\text { CBD-induced inhibition of CYP2D6, CYP3A4/5 can cause unanticipated adverse } \\
\text { reactions and supratherapeutic drug level }\end{array}$ \\
\hline
\end{tabular}




\begin{tabular}{|l|l|l|}
\hline Clozapine & CYP1A2, CYP2D6, CYP3A4/5, P-gp & $\begin{array}{l}\text { THC-induced inhibition of CYP2D6, CYP3A4 can lead to supratherapeutic drug } \\
\text { level and clozapine-induced toxic reactions }\end{array}$ \\
\hline Olanzapine & CYP1A2, P-gp & Induction of CYP1A2 can lead to subtherapeutic drug level or therapeutic failures \\
\hline Quetiapine & CYP3A4/5 & $\begin{array}{l}\text { THC/CBD-induced inhibition of CYP3A4/5 can lead to unanticipated adverse } \\
\text { reactions and supratherapeutic drug level with excessive sedation }\end{array}$ \\
\hline Risperidone & CYP2D6, CYP3A4/5, P-gp & $\begin{array}{l}\text { THC/CBD-induced inhibition of CYP2D6, CYP3A4/5 can lead to unanticipated } \\
\text { adverse reactions and supratherapeutic drug level +/- EPS }\end{array}$ \\
\hline
\end{tabular}

\section{Possible Risks of Cannabis Use for Palliative Psychiatry}

Despite growing research and claimed therapeutic effects of cannabinoids in the field of cancer and palliative medicine, medical practitioners still have reservations about its use. There are several reasons for this, but one of the main concerns is the plethora of possible adverse effects that patients may experience as a result of cannabis use. Studies have shown both short-term and long-term side effects. Some of the short-term side effects include strong psychoactive effects, anxiety, paranoia, and panic attacks, among others. Importantly, previous studies have shown that compared to natural cannabis users, synthetic cannabinoid users experience more severe psychotic symptoms, agitation, anxiety, paranoia, and depression. One study compared depressive symptoms between patients who use predominantly marijuana, and those who use predominantly synthetic cannabinoids. Many synthetic cannabinoids contain added substances (including benzodiazepines and O-desmethyltramadol) to increase their psychoactive effect. This study measured depression using the Beck Depression Inventory and found that, while depression scores were high in both groups, there was a statistically significant increase in depressive symptoms in participants using synthetic cannabinoids compared to those using marijuana ${ }^{[123]}$.

Long-term effects associated with cannabis use include possible cardiovascular, respiratory, and reproductive symptoms as well as changes in bone mineral density and sleep ${ }^{[133]}$. Generally, patients receive insufficient information or assistance about the increasingly popular cannabinoid-based medications from healthcare providers. Cannabis-based management (CBM) may be more effective if physicians communicate the risks and benefits of cannabis to patients ${ }^{[1]}$.

\section{Legality and Use of Medical Cannabis in Palliative Care in the United States}

Over the past few years, the movement to legalize medical cannabis in the United States has gained widespread public attention and support. Although possession and use of cannabis is still illegal under federal law, many states have passed legislation decriminalizing cannabis possession and allowing the medical and/or recreational use of the drug. The uses for medical cannabis are centered around pain control and providing relief from chronic pain ${ }^{[148]}$. These properties are applicable to palliative and hospice care, where the drug can help patients cope with physical and emotional pain from cancer, neurodegenerative diseases, inflammatory diseases, and uncontrolled seizures. This section will explore the current state and federal legislation on medical cannabis and its use for end-of-life care.

\section{Overview of state policies}

As of the writing of this literature review, 36 states, the District of Columbia, Puerto Rico, and the U.S. Virgin Islands have enacted comprehensive policies regarding the distribution and use of medical cannabis. These policies protect individuals using medical cannabis from legal ramifications, outline systems of cannabis distribution, allow a variety of cannabis products (some including those with high-THC content), and permit the smoking and/or vaporization of such products. These 36 states include Alaska, Arizona, Arkansas, California, Colorado, Connecticut, Delaware, Florida, Hawaii, Illinois, Louisiana, Maine, Maryland, Massachusetts, Michigan, and others ${ }^{[149]}$.

Additionally, there are twelve states that allow the use of "low THC, high CBD" products for medical purposes. This is the case in more restrictive states such as Iowa and Texas, in which patients with specified illnesses are able to obtain certain CBDcontaining, low-THC products without legal repercussions. However, these low-THC presentations differ from those used in comprehensive medical marijuana programs, which must meet the following criteria:

1. Grant protection from legal penalties for using marijuana in a medical setting

2. Permit accessibility through cultivation, dispensaries or any other system that grants its provision

3. Allow the use of different product parts and strains with diverse THC concentrations

4. Allow for smoking or vaporization of different derivatives of marijuana

5. Is not considered a limited trial program

In this second group of states, intractable epilepsy is the most common condition for which cannabis products can be obtained. The twelve states forming this group are Alabama, Georgia, Idaho, Indiana, Iowa, Kentucky, North Carolina, South Carolina, Tennessee, Texas, Wisconsin, and Wyoming ${ }^{[149]}$.

States allowing the use of medical marijuana have varying conditions that aid the regulatory process of its possession, dispensing, and registration. Growers and dispensaries are referred to as "caregivers" and may have state-level regulations in terms of recognition and allowed amount of production and distribution. The use of a patient registry or ID card is extensively available, except in the states of Washington and Louisiana, where that condition is currently pending. Dispensaries are allowed in the majority of states, but not in Michigan, which provides alternative ordinances, and some other states have established restrictions to the presentation of their products. For instance, West Virginia does not permit smokable presentations but allows for vaporizable ones. New York has an established maximum of $10 \mathrm{mg}$ of THC per product, which may not be combusted. Minnesota allows liquid extract products only. Most states specify chronic, debilitating conditions that medical cannabis may be used for, except for California, Oklahoma, and Virginia, which have less restrictions and allow patients to get the drug for any condition that a physician may deem appropriate. Most state programs do not accept patients from other states; however, this status is constantly changing among states. State government websites contain more detailed information on medical cannabis possession, form, and cultivation [149].

State versus federal policy

The legal status of cannabis has seen several changes throughout the past century. Extensive review of the literature about cannabis use and regulations shows that its nonmedical use was initially 
prohibited by federal law in 1937 through the Marihuana Tax Act. Later on, its access was further restricted via the Controlled Substances Act in 1970, which designated it as a Schedule I drug, in accordance with the international tendency seen after the United Nations Single Convention on Narcotic Drugs of 1961. Despite some discrepancies, cannabis use saw an initial peak in the youth population in the late 1970s and its use has continued to increase throughout the decades. Although its main use remains recreational (89.5 percent of adult users), a relevant amount (10.5 percent) use it solely for medical purposes, with a considerable percentage (36.1 percent) reporting mixed medical and recreational use ${ }^{[150]}$.

The use of all marijuana remains illegal on a federal level. The federal government still classifies cannabis as a Schedule I drug, along with substances like heroin, MDMA, and methaqualone ${ }^{[151]}$. This means that the federal government considers the drug to have a high potential for abuse and no legitimate medical applications, making possession and distribution of cannabis a federal crime with strictly regulated exceptions. Namely, pharmaceutical-grade cannabinoids are scheduled apart from cannabis, with substances such as dronabinol (purely 9-delta-THC) being sold under prescription and placed in Schedule III. This discrepancy in classification indicates that there is an important lack of recognition of the medicinal uses of the plant as a whole ${ }^{[152]}$.

This federal legal status presents a problem in states with conflicting policies. In practice, however, federal enforcement of these laws is extraordinarily rare due to limited investigative and prosecutorial resources. In 2013, the U.S. Department of Justice stated in the Cole Memorandum that the federal government would adopt a more hands-off approach and defer to state law in jurisdictions that have already implemented regulatory systems regarding the cultivation, distribution, sale, and possession of cannabis ${ }^{[153]}$. This policy was terminated in 2018 , when the former Attorney General Sessions gave federal prosecutors more leeway to decide how to prioritize and enforce federal cannabis laws. However, this has largely been a symbolic gesture, as federal cannabis prosecutions have continued to decline and only proceed in cases that could result in convictions in their districts ${ }^{[149]}$. Therefore, in terms of overall arrests for marijuana offenses, the majority actually take place under state, rather than federal, law. Even so, federal enforcement of marijuana laws presents a challenge in other respects.

A Schedule I classification imposes significant hurdles on conducting research on cannabis, making it difficult for researchers to thoroughly evaluate its safety and efficacy ${ }^{[140]}$. Restrictions are established by imposing the need for extensive administrative reviews on research proposals. Cannabis can only be obtained through a single Drug Enforcement Administration (DEA) regulated grower that is registered for cultivation destined for research, located at the University of Mississippi. It can then be accessed through an application to the National Institute on Drug Abuse (NIDA) drug supply program, but only after the applicant fulfills all registration, application, and review requirements ${ }^{[154]}$.

Regarding interstate regulations, federal law prohibits the transportation of and commerce in marijuana across states, including states where medical marijuana is legalized. In relation to the federal tax code (26 U.S.C. section 280E), marijuana farmers, dispensary owners, and other workers in the marijuana industry are classified as drug traffickers, while marijuana businesses still have to pay federal taxes ${ }^{[155]}$. This renders tax deductions unavailable to them. The imbalance is further exacerbated by the restricted access to banking services, including lines of credit and electronic transfers, among others. This causes many businesses to provide cash-only services that are more vulnerable ${ }^{[111]}$.

\section{Future legislation on medical cannabis}

The legality of medical and recreational cannabis at the state and federal level is shifting quickly, with more states to change their laws in the near future and bipartisan support for legalization in the House and the Senate. Currently, many of the remaining states without medical cannabis programs are reviewing legislation aimed at approving medical cannabis use for those with terminal illnesses. For example, an Alabama bill allowing those with terminal illnesses and a number of other ailments to seek medical cannabis passed the state legislature in May of $2021^{[156]}$. The North Carolina state legislature is also currently reviewing a bill aimed at regulating the sale, possession, and consumption of cannabis. There have also been developments in Congress this year regarding medical cannabis. H.R.365, a bill aiming to reclassify cannabis as a Schedule III drug, was introduced in the House early in $2021^{[157]}$. The SAFE Banking Act of 2021, which would allow legitimate cannabis companies to build relationships with financial institutions without violating federal law, was recently passed in the House ${ }^{[158]}$. This may soon pave the way to solving the conflicts regarding the current status of cannabis and ultimately may allow its legalization at the federal level.

\section{Future Perspectives}

In spite of its legislative restrictions, the accessible clinical research on cannabis has shown that cannabis effectively addresses several issues commonly confronted in palliative care. Research supports the effectiveness of cannabinoids for treating chemotherapy-induced vomiting and nausea, though the data on phytocannabinoids is still being studied ${ }^{[159]}$.

Studies have been made on endocannabinoid transport blockers such as AM404, which inactivate the degradation pathway for endocannabinoids. Its effects result in downstream modulation of 5-HT1A and CB1 receptors. This appears to have anxiolytic-like properties and reduces compulsive behaviors, making it a potential therapy for obsessive-compulsive disorder (OCD). However, research on endocannabinoid transport blockers is still very limited ${ }^{[130]}$.

Further investigation regarding anandamide metabolism may also reveal therapeutic alternatives. Anandamide is believed to be an activity-dependent regulator of monoamine transmission. As anandamide is removed from the synaptic cleft, it is degraded by fatty acid amide hydrolase (FAAH), a membrane-bound enzyme. Studies have found that intercepting this hydrolase may reduce anxiety-like behaviors and induce antidepressant-like effects in animal models. This is likely due to increased anandamide in the prefrontal cortex and in the dorsolateral periaqueductal gray, which modulates the emotional response to stress ${ }^{[130]}$.

Another endocannabinoid that has been described to influence anxiety is 2-AG, which decreases the transmission of GABA and glutamate. 2-AG is degraded by a cytosolic serine hydrolase called monoacylglycerol lipase (MAGL) which, when inhibitedin animal studies, proved to have anxiolytic-like effects in high-stress environments ${ }^{[130]}$.

Regarding palliative care, patients who are on long-term opioids for pain may be treated with cannabis alone or in combination with smaller doses of opioids. Although the efficacy of cannabis in neuropathic pain treatment in conjunction with opioids is limited, it has been well established [160,161]. Cannabinoids will certainly take on a more substantial role in palliative care medicine in the future, but there are still obstacles hindering an unencumbered and safe system for patients ${ }^{[162]}$. From 
a pharmacological standpoint, cannabinoids are much less harmful than opioids, they have a wide range of applications in palliative care, and may present a viable alternative to opioids. As our population grows older, the controversial debate about whether cannabis should be reclassified by the DEA as a Schedule III or higher drug frequently arises ${ }^{[163]}$. If cannabis can be used to relieve chronic pain, it may save thousands of lives from being lost to opioid toxicity. Regarding CBD, its interaction with many channels and receptors needs to be further studied in order to understand the full range of its possible therapeutic uses ${ }^{[108]}$.

Legally, it is important to make a clear distinction between the medical and the recreational use of cannabis. In actuality, there is enough data to explore cannabis as an adjuvant in the treatment of many symptoms frequently encountered in the palliative care setting. A better understanding of cannabis and its medicinal uses would allow for fruitful research in the future.

\section{Conclusion}

As the population of the United States ages, an increasing amount of patients seek access to palliative care services. These patients deserve the best quality of treatment available in order to optimally manage their symptoms and improve quality of life. Medical cannabis shows potential in this field, but there are still many hurdles to overcome, including legislative restrictions and the further understanding of cannabis' safety profile. Although a lot of evidence supports the use of cannabis in palliative care, stronger evidence of its clinical uses in accordance with medical guidelines is still needed. Medical cannabis appears to be a therapeutic alternative with valuable potential, therefore providers and patients need to be more aware of its utility as a treatment option in palliative care. It is hoped that this literature review will provide information and guidance for further studies in this developing field of medical research.

\section{Data Availability}

Data derived from public domain resources and available within the article.

\section{Conflicts of Interest}

The authors declare that there is no conflict of interest regarding the publication of this paper.

\section{Funding Statement}

This research received no specific grant from any funding agency in the public, commercial, or not-for-profit sectors.

\section{Authors' contributions}

V.B. designed the project, the main conceptual ideas and proof outline. V.B., M.K. wrote the manuscript with support from V.M, N.V., C.S. and I.S. V.M, N.V., C.S. and I.S. contributed to the literature search and interpretation of the data. All authors provided critical feedback and helped shape the research, analysis, and the final manuscript. All authors have read and agreed to the published version of the manuscript.

\section{References}

[1] Cyr C, Arboleda MF, Aggarwal SK, Balneaves LG, Daeninck P, Néron A, Prosk E, Vigano A. 2018. Cannabis in palliative care: current challenges and practical recommendations. Annals of Palliative Medicine, 7(4), 463-477. https://doi.org/10.21037/apm.2018.06.04

[2] Bar-Lev Schleider L, Mechoulam R, Lederman V, et al. 2018. Prospective analysis of safety and efficacy of medical cannabis in large unselected population of patients with cancer. Eur J Intern Med 49:37-43. doi:10.1016/j.ejim.2018.01.023

[3] El Sohly,M.A.,andSlade,D.(2005).Chemical constituents of marijuana:the complex mixture of natural cannabinoids. $\quad$ LifeSci. 78, 539548.doi:10.1016/j.lfs.2005.09.011

[4] Mechoulam R, Gaoni Y. 1965. Hashish. IV. Isolation and structure of cannabinolic, cannabidiolic, and cannabigerolic acids. Tetrahedron 21(5):1223-1229.

[5] Pate D. 1999. Anandamide structure-activity relationships and mechanisms of action on intraocular pressure in the normotensive rabbit model. Thesis. University of Kuopio, Kuopio, Finland.

[6] Radwan MM, ElSohly MA, Slade D, Ahmed SA, Khan IA, Ross SA. 2009. Biologically active cannabinoids from high-potency Cannabis sativa. J Nat Prod 72:906911. doi:10.1021/np900067

[7] Fischedick JT, Hazekamp A, Erkelens T, Choi YH, Verpoorte R. 2010. Metabolic fingerprinting of Cannabis sativa L., cannabinoids and terpenoids for chemotaxonomic and drug standardization purposes. Phytochemistry 71:2058-2073. doi:10.1016/j.phytochem.2010.10.001

[8] Health Canada. Cannabis (marihuana, marijuana) and cannabinoids. 2013. Available from: http://www.hcsc.gc.ca/dhp-mps/marihuana/med/infoprof-eng.php

[9] Gaoni Y, Mechoulam R. 1964b. Hashish. III. Isolation, structure, and partial synthesis of an active constituent of hashish. Journal of the American Chemical Society 86(8):1646-1647.

[10] Biegon A, Kerman IA. 2001. Autoradiographic study of pre- and postnatal distribution of cannabinoid receptors in the human brain. Neuro Image 14:1463-1468.

[11] Glass M, Dragunow M, Faull RL. 1997. Cannabinoid receptors in the human brain: a detailed anatomical and quantitative autoradiographic study in the fetal, neonatal and adult human brain. Neuroscience 77:299-318.

[12] MacCallum CA, Russo EB. 2018. Practical considerations in medical cannabis administration and dosing. Eur J Intern Med 49:12-9.

[13] Van Sickle MD, Duncan M, Kingsley PJ, Mouihate A, Urbani P, Mackie K, Stella N, Makriyannis A, Piomelli D, Davison JS, et al. 2005. Identification and functional characterization of brainstem cannabinoid CB2 receptors. Science 310:329-332.

[14] De Petrocellis L, Ligresti A, Moriello AS, Allarà M, Bisogno T, Petrosino S. 2011. Effects of cannabinoids and cannabinoid-enriched Cannabis extraction TRP channels and endocannabinoid metabolic enzymes. Br J Pharmacol 163:1479-1494. doi:10.1111/j.14765381.2010. 01166.x

[15] Pacher P, Bátkai S, Kunos G. 2006. The endocannabinoid system as an emerging target of 
pharmacotherapy. Pharmacol Rev 58:389-462. doi: 10.1124/pr.58.3.2

[16] Russo EB. 2011. Taming THC: potential cannabis synergy and phytocannabinoid-terpenoid entourage effects. $\mathrm{Br} \quad \mathrm{J}$ Pharmacol 163:1344-1364. doi:10.1111/j.1476-5381.2011.01238.x

[17] Burstein S. 2015. Cannabidiol (CBD) and its analogs: a review of their effects on inflammation. Bioorgan Med Chem 23:1377-1385. doi: 10.1016/j.bmc.2015.01.059

[18] Englund AM, Stone J, Morrison PD. 2012. Cannabis in the arm: what can we learn from intravenous cannabinoid studies? Curr Pharmaceut Des 18:4906-4914. doi:10.2174/138161212802884618

[19] Russo EB. 2017. Cannabidiol claims and misconceptions. Trends Pharmacol Sci 38:198-201.

[20] Abrams DI. 2016. Integrating cannabis into clinical cancer care. Curr Oncol 23:S8-S14.

[21] Elmes MW, Kaczocha M, Berger WT, et al. 2015. Fatty acid-binding proteins (FABPs) are intracellular carriers for delta9-tetrahydrocannabinol (THC) and cannabidiol (CBD). J Biol Chem 290:8711-8721.

[22] Campos AC, Fogaca MV, Sonego AB, et al. Cannabidiol, neuroprotection and neuropsychiatric disorders. Pharmacol Res 2016;112: 119-127.

[23] Hill AJ, Williams CM, Whalley BJ, Stephens GJ. 2012. Phytocannabinoids as novel therapeutic agents in CNS disorders. Pharmacol Therapeut 133:79-97. doi:10.1016/j.pharmthera.2011.09.002

[24] Appendino,G.,Gibbons,S.,Giana,A.,Pagani,A.,Grassi,G., andStavri,M.(2008). Antibacterial Cannabinoids From Cannabissativa: a structure-activity study. J. Nat.Prod. 71, 1427-1430.doi:10.1021/np800267

[25] Bergamaschi MM, Queiroz RH, Zuardi AW, et al. 2011. Safety and side effects of cannabidiol, a Cannabis sativa constituent. Curr Drug Saf 6:237-49.

[26] Devinsky O, Cross JH, Wright S. 2017. Trial of cannabidiol for drug-resistant seizures in the dravet syndrome. N Engl J Med 377:699-700.

[27] DeLong GT, Wolf CE, Poklis A, Lichtman AH. 2010. Pharmacological evaluation of the natural constituent of Cannabis sativa, cannabichromene and its modulation by -9-tetrahydrocannabinol. Drug Alcohol Depend 112:126-133. doi:10.1016/j.drugalcdep.2010.05.019

[28] Eisohly HN, Turner CE, Clark AM, Eisohly MA. 1982. Synthesis and antimicrobial activities of certain cannabichromene and cannabigerol related compounds. J Pharm Sci 71:1319-1323. doi:10.1002/jps.2600711204

[29] Davis WM, Hatoum NS. 1983. Neurobehavioral actions of cannabichromene and interactions with delta9tetrahydrocannabinol. Gen Pharmacol Vasc Sys 14:247252. doi:10.1016/0306-3623(83)90004-6

[30] McPartland JM, Russo EB. 2001. Cannabis and cannabis extracts: greater than the sum of their parts? J Cannabis Therapeut 1:103-132. doi:10.1300/J175v01n03_08

[31] Borrelli F, Fasolino I, Romano B, Capasso R, Maiello F, Coppola D. 2013. Beneficial effect of the nonpsychotropic plant cannabinoid cannabigerol on experimental inflammatory bowel disease. Biochem Pharmacol 85:1306-1316. doi:10.1016/j.bcp.2013.01.017

[32] Freeman TP, Hindocha C, Green SF, Bloomfield MAP. Medicinal use of cannabis based products and cannabinoids. BMJ. 2019 Apr 4;365:11141. doi: 10.1136/bmj.11141. PMID: 30948383; PMCID: PMC6447998.

[33] Devane WA, Hanus L, Breuer A, Pertwee RG, Stevenson LA, Griffin G, Gibson D, Mandelbaum A, Ettinger A, Mechoulam R. 1992. Isolation and structure of a brain constituent that binds to the cannabinoid receptor. Science (Wash DC) 258:1946-1949.

[34] Gonsiorek W, Lunn C, Fan X, Narula S, Lundell D, Hipkin RW. 2000. Endocannabinoid 2arachidonoylglycerol is a full agonist through human type 2 cannabinoid receptor: antagonism by anandamide. Mol Pharmacol 57:1045-1050. [PubMed: 10779390]

[35] Schmid PC, Reddy PV, Natarajan V, Schmid HH. 1983. Metabolism on $\mathrm{N}$-acylethanolamine phospholipids by a mammalian phosphodiesterase of the phospholipase D type. J Biol Chem 258:9302-9306.

[36] Mechoulam R, Benshabat S, Hanus L, Ligumsky M, Kaminski NE, Schatz AR, Gopher A, Sholomo A, Martin BR, Compton DR, et al. 1995. Identification of an endogenous 2-monoglyceride, present in canine gut, that binds to cannabinoid receptors. Biochem Pharmacol 50:83-90. [PubMed: 7605349]

[37] Sugiura T, Kondo S, Sukagawa A, Nakane S, Shinoda A, Itoh K, Yamashita A, Waku K. 1995. 2Arachidonoylglycerol: a possible endogenous cannabinoid receptor ligand in the brain. Biochem Biophys Res Commun 215:89-97.

[38] Giuffrida A, Parsons LH, Kerr TM, Rodriguez de Fonseca F, Navarro M, Piomelli D. Dopamine activation of endogenous cannabinoid signaling in dorsal striatum. Nat Neurosci 1999;2:358-363.

[39] Wilson RI, Nicoll RA. Endogenous cannabinoids mediate retrograde signalling at hippocampal synapses.Nature (Lond) 2001;410:588-592.

[40] Varma N, Carlson GC, Ledent C, Alger BE. 2001. Metabotropic glutamate receptors drive the endocannabinoid system in the hippocampus. J Neurosci 21:RC188. [PubMed: 11734603]

[41] Kim J, Isokawa M, Ledent C, Alger BE. 2002. Activation of muscarinic acetylcholine receptors enhances the release of endogenous cannabinoids in the hippocampus. J Neurosci 22:10182-10191. [PubMed: 12451119]

[42] Witting A, Walter L, Wacker J, Moller T, Stella N. 2004. P2X7 receptors control 2-arachidonoylglycerol production by microglial cells. Proc Natl Acad Sci USA 101:3214-3219. [PubMed:14976257]

[43] Di S, Malcher-Lopes R, Marcheselli VL, Bazan NG, Tasker JG. 2005b. Rapid glucocorticoid-mediated endocannabinoid release and opposing regulation of glutamate and $\gamma$-aminobutyric acid inputs to hypothalamic magnocellular neurons. Endocrinology 146:4292-4301.

[44] Maccarrone M. 2017. Metabolism of the endocannabinoid anandamide: open questions after 25 years. Front Mol Neurosci 10:166.

[45] Kaczocha M, Vivieca S, Sun J, Glaser ST, Deutsch DG. 2012. Fatty acid-binding proteins transport Nacylethanolamines to nuclear receptors and are targets of endocannabinoid transport inhibitors. J Biol Chem 287:3415-3424 
[46] Pertwee RG, Ross RA. 2002. Cannabinoid receptors and their ligands. Prostaglandins Leukot Essent Fatty Acids 66:101-121.

[47] Maccarrone M, Finazzi-Agro A. 2002. Endocannabinoids and their actions. Vitam Horm 65:225-255.

[48] Mackie K, Devane WA, Hille B. 1993. Anandamide, an endogenous cannabinoid, inhibits calcium currents as a partial agonist in N18 neuroblastoma cells. Mol Pharmacol 44:498-503.

[49] Matsuda LA, Lolait SJ, Brownstein MJ, Young AC, Bonner TI. 1990. Structure of a cannabinoid receptor and functional expression of the cloned cDNA. Nature 346:561-564.

[50] Di Marzo V, Matias I. 2005. Endocannabinoid control of food intake and energy balance. Nat Neurosci 8:585589

[51] Williams CM, Kirkham TC. Reversal of $\Delta 9$-THC hyperphagia by SR141716 and naloxone but not dexfenfluramine. Pharmacol Biochem Behav 2002;71:341-348.

[52] Ravinet Trillou C, Arnone M, Delgorge C, Gonalons N, Keane P, Maffrand JP, Soubrié P. Anti-obesity effect of SR141716, a CB1 receptor antagonist, in diet-induced obese mice. Am J Physiol 2003;284:R345-R353

[53] Hildebrandt AL, Kelly-Sullivan DM, Black SC. Antiobesity effects of chronic cannabinoid CB1 receptor antagonist treatment in diet-induced obese mice. Eur $\mathbf{J}$ Pharmacol 2003;462:125-132.

[54] Hohmann AG, Martin WJ, Tsou K, Walker JM. Inhibition of noxious stimulus-evoked activity of spinal cord dorsal horn neurons by the cannabinoid WIN 55,212-2. Life Sci 1995;56:2111-2119.

[55] Hohmann AG, Suplita RL, Bolton NM, Neely MH, Fegley D, Mangieri R, Krey JF, Walker JM, Holmes PV, Crystal JD, et al. An endocannabinoid mechanism for stress-induced analgesia. Nature (Lond) 2005;435:11081112.

[56] Glass M. The role of cannabinoids in neurodegenerative diseases. Prog NeuropsychopharmacolBiol Psychiatry 2001;25:743-765.

[57] Mechoulam R, Spatz M, Shohami E. Endocannabinoids and neuroprotection. Sci STKE 2002a;2002:129-RE5.

[58] van der Stelt M, Di Marzo V. The endocannabinoid system in the basal ganglia and in the mesolimbic reward system: implications for neurological and psychiatric disorders. Eur J Pharmacol 2003;480:133-150.

[59] Hall W, Degenhardt L, Teesson M. Cannabis use and psychotic disorders: an update. Drug Alcohol Rev 2004;23:433-443.

[60] Morales M, Wang S-D, Diaz-Ruiz O, Jho DH-J. Cannabinoid $\mathrm{CB} 1$ receptor and serotonin 3 receptor subunit A (5-HT3A) are co-expressed in GABA neurons in the rat telencephalon. J Comp Neurol 2004;468:205216.

[61] Murillo-Rodriguez E, Sanchez-Alavez M, Navarro L, Martinez-Gonzalez D, Drucker-Colin R, Prospero-Garcia O. Anandamide modulates sleep and memory in rats. Brain Res 1998;812:270-274.

[62] De Vries TJ, Schoffelmeer AN. Cannabinoid CB1 receptors control conditioned drug seeking. Trends Pharmacol Sci 2005;26:420-426.
[63] Maldonado R, Valverde O, Berrendero F. Involvement of the endocannabinoid system in drug addiction. Trends Pharmacol Sci 2006;29:225-232.

[64] Hillard CJ. Endocannabinoids and vascular function. J Pharmacol Exp Ther 2000;294:27-32.

[65] Pacher, P.; Bátkai, S.; Kunos, G. Cardiovascular pharmacology of cannabinoids. In: Pertwee, R., editor. Cannabinoids. Springer; New York: 2005b. p. 599-627.

[66] Calignano A, Katona I, Desarnaud F, Giuffrida A, La Rana G, Mackie K, Freund TF, Piomelli D.Bidirectional control of airway responsiveness by endogenous cannabinoids. Nature (Lond) 2000;408:96-101.

[67] Jarvinen T, Pate DW, Laine K. Cannabinoids in the treatment of glaucoma. Pharmacol Ther 2002;95:203220. [PubMed: 12182967]

[68] Tomida I, Pertwee RG, Azuara-Blanco A. Cannabinoids and glaucoma. Br J Ophthalmol 2004;88:708-713.

[69] Coutts AA, Izzo AA. The gastrointestinal pharmacology of cannabinoids: an update. Curr Opin Pharmacol 2004;4:572-579.

[70] Massa F, Storr M, Lutz B. The endocannabinoid system in the physiology and pathophysiology of the gastrointestinal tract. J Mol Med 2005;83:944-954.

[71] Bátkai S, Járai Z, Wagner JA, Goparaju SK, Varga K, Liu J, Wang L, Mirshahi F, Khanolkar AD, Makriyannis A, et al. Endocannabinoids acting at vascular CB1 receptors mediate the vasodilator state in advanced liver cirrhosis. Nat Med 2001;7:827-832.

[72] Ros J, Claria J, To-Figueras J, Planaguma A, CejudoMartin P, Fernandez-Varo G, Martin-Ruiz R, Arroyo V, Rivera F, Rodes J, et al. Endogenous cannabinoids: a new system involved in the homeostasis of arterial pressure in experimental cirrhosis in the rat. Gastroenterology 2002;122:85-93.

[73] Park B, Gibbons HM, Mitchell MD, Glass M. Identification of the CB1 cannabinoid receptor and fatty acid amide hydrolase (FAAH) in the human placenta. Placenta 2003;24:990-995.

[74] Munro S, Thomas KL, Abu-Shaar M. 1993. Molecular characterization of a peripheral receptor for cannabinoids. Nature 365:61-65.

[75] Maresz K, Carrier EJ, Ponomarev ED, Hillard CJ, Dittel BN. 2005. Modulation of the cannabinoid CB2 receptor in microglial cells in response to inflammatory stimuli. $\mathrm{J}$ Neurochem 95:437-445.

[76] Ashton JC, Rahman RM, Nair SM, Sutherland BA, Glass M, Appleton I. 2007. Cerebral hypoxia-ischemia and middle cerebral artery occlusion induce expression of the cannabinoid CB2 receptor in the brain. Neurosci Lett 412:114-117.

[77] Yoshihara S, Morimoto H, Ohori M, Yamada Y, Abe T, Arisaka O. 2005. Endogenous cannabinoid receptor agonists inhibit neurogenic inflammations in guinea pig airways. Int Arch Allergy Immunol 138:80-87.

[78] Zhu LX, Sharma S, Stolina M, Gardner B, Roth MD, Tashkin DP, Dubinett SM. $\Delta$-9-Tetrahydrocannabinol inhibits antitumor immunity by a CB2 receptormediated, cytokine dependent pathway. J Immunol 2000;165:373-380.

[79] Ofek O, Karsak M, Leclerc N, Fogel M, Frenkel B, Wright K, Tam J, Attar-Namdar M, Kram V, Shohami E, et al. Peripheral cannabinoid receptor, CB2, regulates bone mass. Proc Natl Acad Sci USA 2006;103:696-701. 
[80] Rothschild,M.,Bergstrom,G.,andWangberg,S.(2005). Cannabissativa: volatile compounds from pollen and entire male and female plants of two variants, Northern Lights and Hawaian Indica. Bot. J.Linn.Soc. 147, 387397.doi:10.1111/j.1095-8339.2005.00417.x

[81] Brenneisen,R.(2007). "Chemistry and analysis of phytocannabinoids and other cannabis constituents,"in Marijuana and the Cannabinoids Forensic Science and Medicine,

ed.M.ElSohly(NewYork,NY:HumanaPress),1749.doi:10.1007/978-1-59259-947-9_2

[82] Fukumoto, S.,Sawasaki,E.,Okuyama,S.,Miyake,Y., and Yokogoshi,H.(2006).Flavor components of monoterpenes in citrus essential oils enhance the release of monoamines from rat brain slices. Nutr. Neurosci. 9, 73-80.doi:10.1080/10284150600573660

[83] Bowles EJ. The Chemistry of Aromatherapeutic Oils. 3rd edn. Crow's Nest, NSW: Allen \& Unwin; 2003.

[84] Buchbauer G. Biological activities of essential oils. In: Baser KHC, Buchbauer G, editors. Handbook of Essential Oils: Science, Technology, and Applications. Boca Raton, FL: CRC Press; 2010. pp. 235-280.

[85] Komori T, Fujiwara R, Tanida M, Nomura J, Yokoyama MM. Effects of citrus fragrance on immune function and depressive states. Neuroimmunomodulation. 1995 MayJun;2(3):174-80. doi: 10.1159/000096889.

[86] do Vale TG, Furtado EC, Santos JG Jr, Viana GS. Central effects of citral, myrcene and limonene, constituents of essential oil chemotypes from Lippia alba (Mill.) n.e. Brown. Phytomedicine. 2002 Dec;9(8):70914. doi: 10.1078/094471102321621304.

[87] Bisset NG, Wichtl M. Herbal Drugs and Phytopharmaceuticals: A Handbook for Practice on A Scientific Basis. 3rd edn. Boca Raton, FL: Medpharm Scientific Publishers: Stuttgart; CRC Press; 2004.

[88] Russo EB. Handbook of Psychotropic Herbs: A Scientific Analysis of Herbal Remedies for Psychiatric Conditions. Binghamton, NY: Haworth Press; 2001

[89] Rochefort C, Gheusi G, Vincent JD, Lledo PM. Enriched odor exposure increases the number of newborn neurons in the adult olfactory bulb and improves odor memory. $\mathrm{J}$ Neurosci. 2002 Apr 1;22(7):2679-89. doi: 10.1523/JNEUROSCI.22-07-02679.2002.

[90] Delgado P, Moreno F. Antidepressants and the brain. Int Clin Psychopharmacol. 1999 May;14 Suppl 1:S9-16. doi: 10.1097/00004850-199905001-00003.

[91] Russo EB, Guy GW, Robson PJ. Cannabis, pain, and sleep: lessons from therapeutic clinical trials of Sativex, a cannabis-based medicine. Chem Biodivers. 2007 Aug;4(8):1729-43. doi: 10.1002/cbdv.200790150.

[92] Atakan Z. 2012. Cannabis, a complex plant: different compounds and different effects on individuals. Therapeutic Advances in Psychopharmacology, 2(6):241-254.

https://doi.org/10.1177/2045125312457586

[93] Andre CM, Hausman JF, Guerriero G. 2016. Cannabis sativa: the plant of the thousand and one molecules. Frontiers in Plant Science, 7. https://doi.org/10.3389/fpls.2016.00019

[94] Piomelli D, Russo EB. 2016. The Cannabis sativa versus Cannabis indica debate: an interview with Ethan Russo, MD. Cannabis and cannabinoid research, 1(1):44-46. https://doi.org/10.1089/can.2015.29003.ebr
[95] Ferreira FF, Ribeiro FF, Rodrigues RS, Sebastião AM, Xapelli S. 2018. Brain-derived neurotrophic factor (BDNF) role in cannabinoid-mediated neurogenesis. Frontiers in Cellular Neuroscience, 12. https://doi.org/10.3389/fncel.2018.00441

[96] Melas PA, Scherma M, Fratta W, Cifani C, Fadda P. 2021. Cannabidiol as a potential treatment for anxiety and mood disorders: molecular targets and epigenetic insights from preclinical research. International Journal of Molecular $\quad$ Sciences, $22(4): 1863$. https://doi.org/10.3390/ijms22041863

[97] D'Souza DC, Pittman B, Perry E, Simen A. 2008. Preliminary evidence of cannabinoid effects on brainderived neurotrophic factor (BDNF) levels in humans. Psychopharmacology, 202(4):569-578. https://doi.org/10.1007/s00213-008-1333-2

[98] Björkholm C, Monteggia LM. BDNF - a key transducer of antidepressant effects. Neuropharmacology. 2016;102:72-79. doi:10.1016/j.neuropharm.2015.10.034

[99] Lisano JK, Kisiolek JN, Smoak P, Phillips KT, Stewart LK. 2020. Chronic cannabis use and circulating biomarkers of neural health, stress, and inflammation in physically active individuals. Applied Physiology, Nutrition, and Metabolism, 45(3):258-263. https://doi.org/10.1139/apnm-2019-0300

[100] Toll A, Bergé D, Burling K, Scoriels L, Treen D, Monserrat C, Marmol F, Duran X, Jones PB, Pérez-Solà V, Fernandez-Egea E, Mané A. 2020. Cannabis use influence on peripheral brain-derived neurotrophic factor levels in antipsychotic-naïve first-episode psychosis. European Archives of Psychiatry and Clinical Neuroscience, 270(7):851-858. https://doi.org/10.1007/s00406-020-01117-y

[101] Silote GP, Sartim A, Sales A, Eskelund A, Guimarães F, Wegener G, Joca S. 2019. Emerging evidence for the antidepressant effect of cannabidiol and the underlying molecular mechanisms. Journal of Chemical Neuroanatomy, 98:104-116. https://doi.org/10.1016/j.jchemneu.2019.04.006

[102] Sales AJ, Fogaça MV, Sartim AG, Pereira VS, Wegener G, Guimarães FS, Joca SRL. 2018. Cannabidiol Induces Rapid and Sustained Antidepressant-Like Effects Through Increased BDNF Signaling and Synaptogenesis in the Prefrontal Cortex. Molecular Neurobiology, 56(2):1070-1081. https://doi.org/10.1007/s12035-0181143-4

[103] Jose Miguez M, Chan W, Espinoza L, Tarter R, Perez C. 2019. Marijuana use among adolescents is associated with deleterious alterations in mature BDNF. AIMS Public Health, 6(1):4-14. https://doi.org/10.3934/publichealth.2019.1.4

[104] Muller, C., Morales, P., \& Reggio, P. H. (2019). Cannabinoid Ligands Targeting TRP Channels. Frontiers in molecular neuroscience, 11, 487. https://doi.org/10.3389/fnmol.2018.00487

[105] Pertwee RG. The diverse CB1 and CB2 receptor pharmacology of three plant cannabinoids: delta9tetrahydrocannabinol, cannabidiol and delta9tetrahydrocannabivarin. $\mathrm{Br} \quad \mathrm{J}$ Pharmacol. 2008;153(2):199-215. doi:10.1038/sj.bjp.0707442

[106] Han K.H., Lim S., Ryu J., Lee C.W., Kim Y., Kang J.H., Kang S.S., Ahn Y.K., Park C.S., Kim J.J. CB1 and CB2 cannabinoid receptors differentially regulate the 
production of reactive oxygen species by macrophages. Cardiovasc. Res. 2009;84:378-386. doi: 10.1093/cvr/cvp240.

[107] Atalay S, Jarocka-Karpowicz I, Skrzydlewska E. Antioxidative and Anti-Inflammatory Properties of Cannabidiol. Antioxidants (Basel). 2019;9(1):21. Published 2019 Dec 25. doi:10.3390/antiox9010021

[108] Nagarkatti P, Pandey R, Rieder SA, Hegde VL, Nagarkatti M. 2009. Cannabinoids as novel antiinflammatory drugs. Future medicinal chemistry, 1(7):1333-1349. https://doi.org/10.4155/fmc.09.93

[109] Dzierżanowski T. 2019. Prospects for the use of cannabinoids in oncology and palliative care practice: A review of the evidence. Cancers, 11(2):129. https://doi.org/10.3390/cancers11020129

[110] Institute of Medicine (US). 1999. Marijuana and medicine: assessing the science base. Washington, DC: National Academy Press. https://pubmed.ncbi.nlm.nih.gov/25101425/

[111] National Academies of Sciences, Engineering, and Medicine. 2017. The health effects of cannabis and cannabinoids: the current state of evidence and recommendations for research. Washington, DC: The National Academies Press. https://doi.org/10.17226/24625

[112] Zhang H, Xie M, Archibald SD, Jackson BS, Gupta MK. 2018. Association of marijuana use with psychosocial and quality of life outcomes among patients with head and neck cancer. JAMA Otolaryngology-Head \& Neck Surgery, 144(11):1017. https://doi.org/10.1001/jamaoto.2018.0486

[113] Sherva R, Wang Q, Kranzler H, Zhao H, Koesterer R, Herman A, Farrer LA, Gelernter J. 2016. Genome-wide association study of cannabis dependence severity, novel risk variants, and shared genetic risks. JAMA Psychiatry 73(5):472-480.

https://doi.org/10.1001/jamapsychiatry.2016.0036

[114] MacDonald E, Farrah K. 2019. Medical cannabis use in palliative care: review of clinical effectiveness and guidelines - an update [Internet]. Ottawa $(\mathrm{ON})$ : Canadian Agency for Drugs and Technologies in Health. https://www.ncbi.nlm.nih.gov/books/NBK551867/

[115] Anderson SP, Zylla DM, McGriff DM, Arneson TJ. 2019. Impact of medical cannabis on patient-reported symptoms for patients with cancer enrolled in Minnesota's medical cannabis program. Journal of Oncology Practice, 15(4):e338-e345. https://doi.org/10.1200/jop.18.00562

[116] Corroon J, Mischley L, Sexton M. 2017. Cannabis as a substitute for prescription drugs - a cross-sectional study. Journal of Pain Research, 10:989-998. https://doi.org/10.2147/jpr.s134330

[117] Feingold D, Weinstein A. 2020. Cannabis and depression. Cannabinoids and Neuropsychiatric Disorders, 67-80. https://doi.org/10.1007/978-3-03057369-0_5

[118] Black, N., Stockings, E., Campbell, G., Tran, L., Zagic, D., Hall, W. D., Farrell, M., Degenhardt, L. (2019). Cannabinoids for the treatment of mental disorders and symptoms of mental disorders: a systematic review and meta-analysis. The Lancet Psychiatry, 6(12), 995-1010. https://doi.org/10.1016/s2215-0366(19)30401-8
[119] Sherva R, Wang Q, Kranzler H, Zhao H, Koesterer R, Herman A, Farrer LA, Gelernter J. 2016. Genome-wide association study of cannabis dependence severity, novel risk variants, and shared genetic risks. JAMA Psychiatry 73(5):472-480.

https://doi.org/10.1001/jamapsychiatry.2016.0036

[120] Serra G, Fratta W. 2007. A possible role for the endocannabinoid system in the neurobiology of depression. Clin Pract Epidemiol Ment Health 3, 25. https://doi.org/10.1186/1745-0179-3-25

[121] El-Alfy AT, Ivey K, Robinson K, et al. Antidepressantlike effect of delta9-tetrahydrocannabinol and other cannabinoids isolated from Cannabis sativa L. Pharmacol Biochem Behav. 2010;95(4):434-442. doi:10.1016/j.pbb.2010.03.004

[122] Forester, B. P. (2019, July 31). Study of dronabinol treatment for depression and/or anxiety in older patients. Retrieved August 14, 2021, from https://clinicaltrials.gov/ct2/show/record/NCT03369639

[123] Görgülü and Sevindik. Clin Med Rev Case Rep 2020, 7:298 DOI: 10.23937/2378-3656/1410298

[124] DeLuca, J., Berwaerts, J., \& Wagner, J. (2021). Effect of nabiximols cannabinoid oromucosal spray on depressive symptoms, suicidality, and cognition in persons with multiple sclerosis (PwMS) (1862). Neurology, 96(15).

[125] Allsop DJ, Copeland J, Lintzeris N, et al. Nabiximols as an agonist replacement therapy during cannabis withdrawal: a randomized clinical trial. JAMA Psychiatry. 2014;71(3):281-291. doi:10.1001/jamapsychiatry.2013.3947

[126] Hegazy O, Platnick H. 2019. Cannabidiol (CBD) for treatment of neurofibromatosis-related pain and concomitant mood disorder: a case report. Cureus, 11(12):e6312. https://doi.org/10.7759/cureus.6312

[127] Calapai G, Mannucci C, Chinou I, Cardia L, Calapai F, Sorbara EE, Firenzuoli B, Ricca V, Gensini GF, Firenzuoli F. 2019. Preclinical and clinical evidence supporting use of cannabidiol in psychiatry. Evidencebased complementary and alternative medicine: eCAM, 2509129. https://doi.org/10.1155/2019/2509129

[128] Khan, R., Naveed, S., Mian, N., Fida, A., Raafey, M. A., \& Aedma, K. K. (2020). The therapeutic role of cannabidiol in mental health: A systematic review. Journal of Cannabis Research, 2(1). https://doi.org/10.1186/s42238-019-0012-y

[129] Garakani, A., Murrough, J. W., Freire, R. C., Thom, R. P., Larkin, K., Buono, F. D., \& Iosifescu, D. V. (2020). Pharmacotherapy of anxiety disorders: Current and emerging treatment options. Frontiers in Psychiatry, 11. Published. https://doi.org/10.3389/fpsyt.2020.595584

[130] Tambaro S, Bortolato M. Cannabinoid-related agents in the treatment of anxiety disorders: current knowledge and future perspectives. Recent Pat CNS Drug Discov. 2012;7(1):25-40. doi:10.2174/157488912798842269

[131] Fabre, L. F., \& McLendon, D. (1981). The efficacy and safety of nabilone (a synthetic cannabinoid) in the treatment of anxiety. The Journal of Clinical Pharmacology, 21(S1), 377S-382S. https://doi.org/10.1002/j.1552-4604.1981.tb02617.x

[132] Whiting PF, Wolff RF, Deshpande S, di Nisio M, Duffy S, Hernandez AV, Keurentjes JC, Lang S, Misso K, Ryder S, Schmidlkofer S, Westwood M, Kleijnen J. 
2015. Cannabinoids for medical use. JAMA, 313(24):2456. https://doi.org/10.1001/jama.2015.6358

[133] Kleckner AS, Kleckner IR, Kamen CS, Tejani MA, Janelsins MC, Morrow GR, Peppone LJ. 2019. Opportunities for cannabis in supportive care in cancer. Therapeutic Advances in Medical Oncology, 11, https://doi.org/10.1177/1758835919866362

[134] Andrade C. Cannabis and neuropsychiatry, 1: benefits and risks. J Clin Psychiatry. 2016;77(5):e551-e554. doi:10.4088/JCP.16f10841

[135] Gage SH, Jones HJ, Burgess S, et al. Assessing causality in associations between cannabis use and schizophrenia risk: a two-sample Mendelian randomization study. Psychol Med. 2017;47(5):971-980. doi:10.1017/S0033291716003172

[136] Reblin M, Sahebjam S, Peeri NC, Martinez YC, Thompson Z, Egan KM. Medical Cannabis Use in Glioma Patients Treated at a Comprehensive Cancer Center in Florida. J Palliat Med. 2019;22(10):1202-1207. doi:10.1089/jpm.2018.0528

[137] Bahorik AL, Sterling SA, Campbell CI, Weisner C, Ramo D, Satre DD. 2018. Medical and non-medical marijuana use in depression: longitudinal associations with suicidal ideation, everyday functioning, and psychiatry service utilization. Journal of Affective Disorders, 241:8-14. https://doi.org/10.1016/j.jad.2018.05.065

[138] Pergam SA, Woodfield MC, Lee CM, Cheng G, Baker KK, Marquis SR, Fann JR. 2017. Cannabis use among patients at a comprehensive cancer center in a state with legalized medicinal and recreational use. Cancer, 123(22):4488-4497. https://doi.org/10.1002/cncr.30879

[139] Passik SD, Theobald DE. Managing addiction in advanced cancer patients: why bother? J Pain Symptom Manage. 2000;19(3):229-234. doi:10.1016/s08853924(00)00109-3

[140] Beresford L. 2021. Navigating medical cannabis is continuing challenge in hospice and palliative care. CSU Shiley Institute for Palliative Care. https://csupalliativecare.org/navigating-medicalcannabis-is-continuing-challenge-in-hospice-andpalliative-care/.

[141] Shah A, Hayes CJ, Lakkad M, Martin BC. 2019. Impact of medical marijuana legalization on opioid use, chronic opioid use, and high-risk opioid use. Journal of general internal medicine, 34(8):1419-1426. https://doi.org/10.1007/s11606-018-4782-2

[142] García-Gutiérrez MS, Navarrete F, Gasparyan A, Austrich-Olivares A, Sala F, Manzanares J. 2020. Cannabidiol: a potential new alternative for the treatment of anxiety, depression, and psychotic disorders. Biomolecules,

10(11):1575. https://doi.org/10.3390/biom10111575

[143] Rong C, Carmona NE, Lee YL, Ragguett RM, Pan Z, Rosenblat JD, Subramaniapillai M, Shekotikhina M, Almatham F, Alageel A, Mansur R, Ho RC, McIntyre RS. 2018. Drug-drug interactions as a result of coadministering $\triangle 9$-THC and CBD with other psychotropic agents. Expert opinion on drug safety, 17(1):51-54. https://doi.org/10.1080/14740338.2017.1397128

[144] Qian Y, Gurley BJ, Markowitz JS. 2019. The potential for pharmacokinetic interactions between cannabis products and conventional medications. Journal of clinical psychopharmacology, 39(5):462-471. https://doi.org/10.1097/JCP.0000000000001089

[145] Bouquié R, Deslandes G, Mazaré H, Cogné M, Mahé J, Grégoire M, Jolliet P. 2018. Cannabis and anticancer drugs: societal usage and expected pharmacological interactions - a review. Fundam Clin Pharmacol 32:462484. doi: 10.1111/fcp.12373.

[146] Alsherbiny MA, Li CG. 2018. Medicinal cannabispotential drug interactions. Medicines (Basel, Switzerland), 6(1):3. https://doi.org/10.3390/medicines6010003

[147] Ganoci et al., Prog Neuropsychopharmacol Biol Psychiatry 2020; 10(104):110042).

[148] Grinspoon P. 2018. Medical marijuana. Harvard Health Publishing.

https://www.health.harvard.edu/blog/medical-marijuana2018011513085.

[149] National Conference of State Legislatures (NCSL). (2021, April 5). State Medical Marijuana Laws. https://www.ncsl.org/research/health/state-medicalmarijuana-laws.aspx.

[150] Schauer GL, King BA, Bunnell RE, Promoff G, McAfee TA. Toking, Vaping, and Eating for Health or Fun: Marijuana Use Patterns in Adults, U.S., 2014. Am J Prev Med. 2016;50(1):1-8. doi:10.1016/j.amepre.2015.05.027

[151] Mead A. Legal and Regulatory Issues Governing Cannabis and Cannabis-Derived Products in the United States. Front Plant Sci. 2019;10:697. Published 2019 Jun 14. doi:10.3389/fpls.2019.00697

[152] Bridgeman MB, Abazia DT. Medicinal Cannabis: History, Pharmacology, And Implications for the Acute Care Setting. P T. 2017;42(3):180-188.

[153] Chadi N, Weitzman ER, Levy S. Understanding the Impact of National and State Medical Marijuana Policies on Adolescents. Current Addiction Reports. 2018. Copy at https://j.mp/2sKCeQc

[154] National Institute on Drug Abuse (NIDA). 2020. NIDA's role in providing marijuana for research. NIH. https://www.drugabuse.gov/drug-topics/marijuana/nidasrole-in-providing-marijuana-research

[155] Owens-Ott GS. Accounting and the US cannabis industry: federal financial regulations and the perspectives of Certified Public Accountants and cannabis businesses owners. J Cannabis Res. 2020;2(1):41. Published 2020 Dec 3. doi:10.1186/s42238-020-00049-7

[156] Zvonarev V, Fatuki TA, Tregubenko P. The Public Health Concerns of Marijuana Legalization: An Overview of Current Trends. Cureus. 2019;11(9):e5806. Published 2019 Sep 30. doi:10.7759/cureus.5806

[157] GovTrack.us. 2021. H.R. $365-117$ th Congress: Marijuana 1-to-3 Act of 2021. https://www.govtrack.us/congress/bills/117/hr365

[158] Lutz JA, Willis AM, Tilton T, Bright T. 2021. SAFE Banking Act of 2021 to provide cannabis industry access to financial services, but obstacles remain. Lexology. https://www.lexology.com/library/detail.aspx?g=3d3488 5b-9607-476d-83ba-1b9792fcd1ec.

[159] Franklin GM, Mai J, Wickizer T, Turner JA, FultonKehoe D, Grant L. 2005. Opioid dosing trends and mortality in Washington State workers' compensation, 1996-2002. American Journal of Industrial Medicine, 48(2):91-99. https://doi.org/10.1002/ajim.20191 
[160] Russo EB. 2008. Cannabinoids in the management of difficult to treat pain. Therapeutics and clinical risk management,

4(1):245-259. https://doi.org/10.2147/tcrm.s1928

[161] Reiman A, Welty M, Solomon P. 2017. Cannabis as a substitute for opioid-based pain medication: patient selfreport. Cannabis and cannabinoid research, 2(1):160166. https://doi.org/10.1089/can.2017.0012

[162] Aggarwal SK, Carter GT, Zumbrunnen C, Morrill R, Sullivan M, Mayer JD. 2013. From 32 ounces to zero: a medical geographic study of dispensing a cultivated batch of "Plum" cannabis flowers to medical marijuana patients in Washington State. Journal of Psychoactive Drugs,

45(2):141-155 https://doi.org/10.1080/02791072.2013.785835

[163] Aggarwal SK, Carter GT, Sullivan MD, ZumBrunnen C, Morrill R, Mayer JD. 2018. Medicinal use of cannabis in the United States: historical perspectives, current trends, and future directions. Journal of Opioid Management, 5(3):153. https://doi.org/10.5055/jom.2009.0016 